UNIVERSIDADE DE SÃO PAULO

FACULDADE DE FILOSOFIA, LETRAS E CIÊNCIAS HUMANAS

DEPARTAMENTO DE LETRAS MODERNAS

PROGRAMA DE PÓS-GRADUAÇÃO EM LITERATURA ESPANHOLA

\title{
DON JUAN E A CONSTRUÇÃO DE UM MITO EM EL BURLADOR DE SEVILLA
}

LILIAN DOS SANTOS SILVA RIBEIRO

Dissertação apresentada ao Programa de Pós-Graduação em Literatura Espanhola, do Departamento de Letras Modernas da Faculdade de Filosofia, Letras e Ciências Humanas da Universidade de São Paulo, para obtenção do título de Mestre em Letras.

Orientador: Prof. Dr. Mario Miguel González 
UNIVERSIDADE DE SÃO PAULO

FACULDADE DE FILOSOFIA, LETRAS E CIÊNCIAS HUMANAS

DEPARTAMENTO DE LETRAS MODERNAS

PROGRAMA DE PÓS-GRADUAÇÃO EM LITERATURA ESPANHOLA

\section{DON JUAN E A CONSTRUÇÃO DE UM MITO EM EL BURLADOR DE SEVILLA}

LILIAN DOS SANTOS SILVA RIBEIRO

São Paulo

2007 


\section{DEDICATÓRIA}

Dedico este trabalho:

ao Patrick, por me mostrar a leveza essencial da vida e a real natureza do amor;

aos meus irmãos, Paula e Leandro, e sobrinhos, Caio e Pietra, pela família que somos e seremos;

e especialmente aos meus pais, Benedicto e Madalena, por me educarem para a tolerância e para a liberdade. 


\section{AGRADECIMENTOS}

Agradeço a todos aqueles que direta ou indiretamente contribuíram para a conclusão deste trabalho, seja em termos materiais ou afetivos:

- Mario González, pela orientação efetiva, atenciosa, e, acima de tudo, democrática;

- Aos meus colegas e alunos do Español en el campus, pelo companheirismo que nos uniu;

- Aos meu amigos queridos e companheiros de universidade: Ana Paula, Ana Cruz, Andréa, Cecília, Cibelle, Edina, Élcio, Mirian, Nalvo, Rossana e Solange, pelo apoio emocional.

O presente trabalho foi realizado com o apoio do Conselho Nacional de Desenvolvimento Científico e Tecnológico - CNPQ - Brasil. 


\title{
RESUMO
}

O presente trabalho visa delimitar quais os fatores os fatores constitutivos da peça El burlador de Sevilla, tanto do ponto de vista histórico - isto é, os fatores sociais, políticos e religiosos -, quanto do ponto de vista da estrutura literária - relacionados à forma artística em que os primeiros ganham forma -, e o modo como esses fatores se relacionam na composição do mito que sustenta o enredo da obra.

\begin{abstract}
The present work intents to delimitate what are the containing factors from the play El burldor de Sevilla, by the historic view - social, politics and religious facts - as well as the literary structure view - related to the artistc form in which the previuous ones gain shape -, and the way those factors associate to each other compounding the plot sustaining myth.
\end{abstract}

\section{PALAVRAS-CHAVE (KEY WORDS)}

Don Juan, Convidado de pedra, Mito, Tirso de Molina, Siglo de Oro Don Juan, Stone guest, Myth, Tirso de Molina, Spanish Golden Century 


\section{SUMÁRIO}

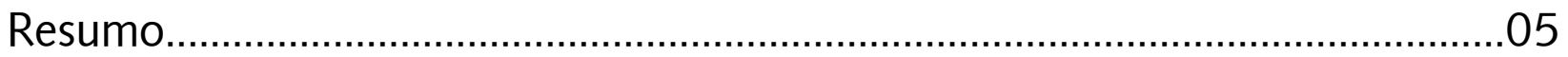

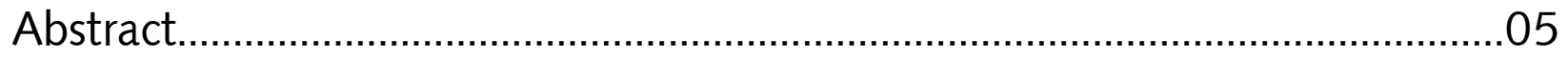

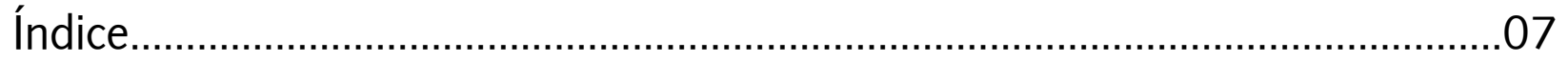

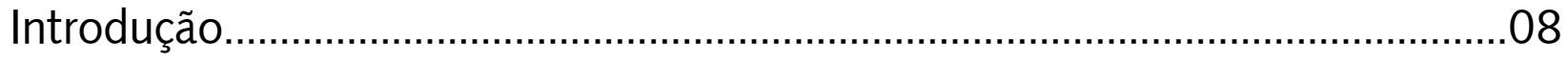

Capítulo 1: A finalidade moral: Don Juan como exemplum...............................10

Capítulo 2: Uma construção alegórica............................................................42

Capítulo 3: O confronto entre dois absolutos................................................63

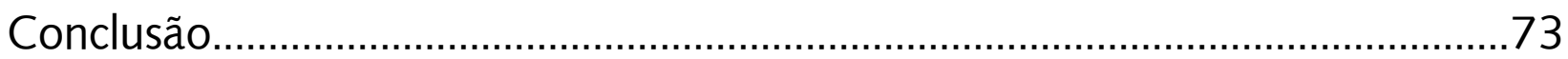

Referências bibliográficas......................................................................... 75 


\section{ÍNDICE}

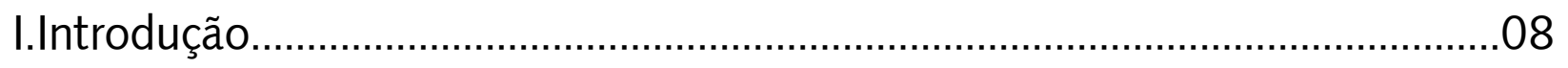

II. Capítulo 1: A finalidade moral: Don Juan como exemplum............................10

1. 1.: A questão do livre arbítrio e a escolha de Don Juan...............10 1.1.1.: A obra versus a fé............................................................11

1. 2.: A Igreja e o Estado: o corpo místico espanhol........................19

1.2.1.: Uma sociedade contra o indivíduo....................................19

1.2.1.1.: Os conceitos de gloria, honore virtus...........................21

1.2.1.2.: As leis deste mundo......................................................30

III. Capítulo 2: Uma construção alegórica.............................................................42

2. 1.: A fábula teatral: alegoria e didatismo.....................................42

2.1.2.: Formação de Don Juan por antítese..................................46

2. 2.: Signos convencionais em El burldor de Sevilla.......................52

2.2.1.: Origem folclórica..............................................................52

2.2.2.: A honra aldeã e o vício cortesão........................................55

2.2.3.: Tópica do burlador burlado................................................59

IV. Capítulo 3: O confronto entre dois absolutos................................................63

3. 1.: Ser e não ser - eis Don Juan.................................................63

3. 2.: Funções do mito....................................................................65

3.2.1.: Caráter sobre-humano.....................................................

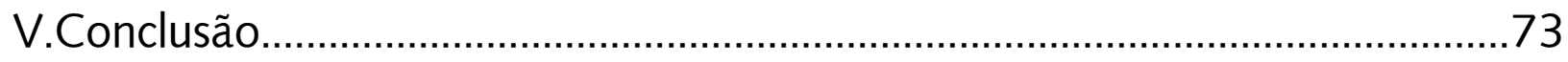

VI. Referências bibliográficas..............................................................................75 


\title{
INTRODUÇÃO
}

O ponto de partida deste estudo é a análise dos fatores constitutivos da peça El burlador de Sevilla, atribuída a Tirso de Molina, tanto pelas determinantes político-religiosas, quanto pela sua formalização dramática, com vistas a delinear o caráter mítico de Don Juan Tenorio.

$\mathrm{Na}$ tentativa de abordar de uma forma mais abrangente a construção de Don Juan, nos convém adotar uma dupla aproximação, o que certamente tornará mais clara a imagem final a que pretendemos chegar. No primeiro tópico de aproximação, trataremos de analisar os fatores que dizem respeito ao seu entorno social, o ideário que fornece o tema da peça. No segundo ponto da abordagem, será analisada a personagem no contexto mesmo da obra, tratando-se de comprovar que sua configuração é principalmente de natureza mítica, ultrapassando a simples ilustração do tema, sobretudo ao confrontar-se com a estátua de Don Gonzalo, que é a personagem mítica à qual se contrapõe.

Nossa tentativa de análise por meio de duas abordagens aparentemente opostas - isto é, uma abordagem que se pauta em elementos sociais que se manifestam na peça, e outra que se pauta nos elementos mítico-literários que a estruturam de fato - revela-se necessária se quisermos abranger o maior número possível de aspectos componentes da obra. No que diz respeito a esse método de análise, temos em mente as palavras de Antonio Candido:

\begin{abstract}
A tentativa de focalizar simultaneamente a obra como realidade própria, e o contexto como sistema de obras, parecerá ambiciosa a alguns, dada a força com que se arraigou o preconceito do divórcio entre história e estética, forma e conteúdo, erudição e gosto, objetividade e apreciação. Uma crítica equilibrada não pode, todavia, aceitar estas falsas incompatibilidades, procurando, ao contrário, mostrar que são partes de uma explicação tanto quanto possível total, que é o ideal do crítico, embora nunca atingido em virtude das limitações individuais e metodológicas. ${ }^{1}$
\end{abstract}

\footnotetext{
${ }^{1}$ CANDIDO, Antonio. Formação da literatura brasileira: 1750-1836. São Paulo: Livraria Martins, $4^{a}$ edição, p. 31.
} 
Assim, este trabalho levanta questões cuja finalidade última é a confirmação do uso ideológico - de uma ideologia em total conformidade à sociedade absolutista espanhola do século XVII — de uma estrutura literária mítica por parte do autor de El burlador de Sevilla, com o sentido de reforçar a transmissão de uma moralidade através do exemplo teatral. 


\section{CAPÍTULO 1}

\section{A FINALIDADE MORAL: DON JUAN COMO EXEMPLUM.}

Neste capítulo, tratamos de averiguar os principais fatores extra-literários que concorrem para a composição do enredo e das personagens da peça El burlador de Sevilla, e que the dão um sentido de exemplaridade didática ao pôr em cena conceitos religiosos, políticos, sociais e morais que deveriam ser apreendidos por seu público.

\section{A QUESTÃO DO LIVRE-ARBÍTRIO E A ESCOLHA DE DON JUAN.}

O primeiro aspecto a ser considerado quando empreendemos uma análise da peça El burlador de Sevilla é o fato de que se trata, antes de mais nada, de uma obra que serve à atuação explícita da Contra-Reforma espanhola. O crítico literário John Varey considera que o tema da peça é o arrependimento oportuno²; parece-nos, porém, que talvez seja mais acertado afirmar que o tema central seja o bom uso do livre-arbítrio, como algo que antecede o arrependimento, já que este é paliativo, e o outro é preventivo dos pecados que poderiam ser cometidos, mas que a doutrina trata de evitar. Faremos um breve trajeto sobre o pensamento de Santo Agostinho, quem forneceu a base, tão longamente aplicada pela Igreja, a respeito do conceito de livrearbítrio, e também sobre Lutero, para em seguida notarmos como se dá, na obra, o rechaço à visão protestante.

\footnotetext{
${ }^{2}$ VAREY, J. E. Cosmovisión y escenografía: el teatro español en el siglo de oro. Madrid: Castalia, 1990.
} 


\section{AS OBRAS VERSUS A FÉ}

Um dos principais ensinamentos que o público de El burlador de Sevilla deveria depreender é o de que a obra do homem deve ser superior à sua fé. $O$ espectador poderia dar-se conta de que Don Juan tem alguma fé, já que não chega a formular uma negação da existência de Deus e da punição, como podemos comprovar em seu famoso refrão "¡Tan largo me lo fiáis!" ("Tenho tempo de sobra”), pois seria completamente diferente se ele afirmasse não acreditar no castigo, ou risse das admoestações - como o refrão "No hay plazo que no llegue, ni deuda que no se pague" ("Não há prazo que não chegue, nem dívida que não se pague") - como se não passassem de singelas crendices. O caráter didático-moralizante da obra parece estar na base dessa ausência de crítica teórica. Afinal, a transgressão de Don Juan só poderia ser justificada pelo seu autor como oriunda da busca por um prazer profano e inconseqüente, de quem não respeita as leis deste e do outro mundo, tornando-se um pecador. Mas a personagem jamais poderia estar dotada de uma fundamentação teórica que justificasse tal transgressão. Na tentativa de imprimir a lição de moral nos espectadores, a repetição de "¡Tan largo me lo fiáis!" só pode caracterizar o pecador contumaz, que pensa em obter o perdão na hora da morte. ${ }^{3} \mathrm{O}$ problema é que a personagem acredita que pode pedir perdão um dia, e ser salva pelo arrependimento ainda que, no seu caso, não seja possível haver uma verdadeira contrição. Mas a ênfase na importância da obra humana nos leva a pensar que o autor conseguiu levar ao palco a Contra-Reforma: a fé não é o suficiente para justificar o pecador. Nesse sentido, presentifica-se a noção de que a fé sem obras é inútil, matéria morta, como lemos na Epístola de Tiago:

Queres, pois, ficar certo, ó homem insensato, de que a fé sem as obras é inoperante? Não foi por obras que Abraão, o nosso pai, foi justificado, quando ofereceu sobre o altar o próprio filho Isaque? Vês como a fé

\footnotetext{
${ }^{3}$ Segundo o crítico Ramiro de Maeztu, Don Juan não é um cético, e sim um soberbo, pois se fosse cético o convite à estátua de pedra seria absurdo. In: MAEZTU, R. Don Quijote, Don Juan y La Celestina. Madrid: 1981. Espasa-Calpe. p. 85.
} 
operava juntamente com as suas obras; com efeito, foi pelas obras que a fé se consumou (...) Verificais que uma pessoa é justificada por obras e não por fé somente (...) porque assim como o corpo sem espírito é morto, assim também a fé sem obras é morta. ${ }^{4}$

Sob esse aspecto, a obra configura-se como mais uma defesa católica contra o Protestantismo, já que o tratamento que dá às noções de pecado e salvação diverge radicalmente à visão de Lutero que, em seu sermão Duas espécies de justiça, de $1519^{5}$, nega a idéia patrística tradicional de justificação do homem como decorrente de um processo gradativo de erradicação dos pecados. Lutero propõe a fides apprehensiva, que capacita o pecador a captar a justiça de Cristo, tornando-se uno com ele. A justiça é sempre extranea, sem merecimento do fiel, dada somente pela graça. $O$ crente é sempre simul justus et peccator. Seus pecados não se apagam, mas sua fé garante que deixem de pesar contra ele. O cristão é morador de dois reinos: o de Cristo e o das coisas mundanas, e sua justificação vem antes da santificação, pois esta última, sim, é gradual e começa logo após o pecador ter adquirido a fé. Lutero também estabelece, em Liberdade de um cristão ${ }^{6}$, de 1520, uma antítese entre os mandamentos divinos do Velho Testamento, que considera impossíveis de serem cumpridos, e a promessa de redenção do Novo Testamento. Afirma que o primeiro tem a função de mostrar ao homem sua própria incapacidade de ser virtuoso e fazê-lo desesperar-se diante disso. O Novo Testamento serviria, então, para reconfortar-nos, mostrando que ainda que não possamos atingir a salvação através do cumprimento irrestrito dos mandamentos, podemos consegui-la através da fé. Mais tarde, em A servidão da vontade $^{7}$, apesar de não negar o valor da razão natural, opõe-se à tese humanística de Erasmo, segundo a qual o homem tem a oportunidade de utilizar seus poderes racionais para descobrir como Deus quer que ele aja. Para Lutero, não se pode medir Deus pela razão humana, nem entender os mistérios da Sua vontade. Somos todos frutos do pecado original e por isso estamos condenados à nossa natureza contrária e

${ }^{4}$ Tiago: 2: 20-26. BíBLIA SAGRADA. Trad. João Ferreira de Almeida. São Paulo: Sociedade Bíblica do Brasil, 1993.

5 LUTERO, M. Apud: SKINNER, Q. As fundações do pensamento político moderno. São Paulo: Companhia das Letras, 2003, p. 290.

${ }^{6}$ Idem, Ibidem, p. 292.

${ }^{7}$ LUTERO, M. Apud: SKINNER, Q. Op. cit., p.287. 
má. Os mandamentos divinos devem ser obedecidos apenas por provirem de Deus, parecendo-nos justos ou não, divergindo da percepção tomística e humanística, que entendia Deus como uma espécie de "legislador racional". A justificação sola fide (pela fé apenas) exclui a possibilidade de o cristão justificar-se (salvar-se) por mérito de suas obras. Porém, o protestante acrescenta que está ao alcance de todos a percepção da gratia de Deus - a graça salvadora concedida por Ele àqueles que predestinou para a salvação. Essa graça constitui um favor fora de proporção com o mérito humano: o pecador deve visar diretamente a fidúcia, ou seja, a fé passiva na justiça divina e na possibilidade de obter a justificação através da Sua misericórdia. Esse pensamento é antitético ao vigente na Igreja Católica, que propõe a existência da sindérese, iluminação dada por Deus aos homens, que os capacita a distinguir as duas coisas e concluir, racionalmente, qual ação $O$ agradaria, enquanto que a lex pecati luterana prevê a incapacidade humana de julgar o Bem e o Mal, incapacidade esta decorrente da mácula hereditária do pecado original.

Podemos perceber em El burlador de Sevilla que Don Juan Tenorio é alguém capaz de discernir o Bem e o Mal, sendo "muito católico" nesse sentido, afastando-se de qualquer traço de ceticismo ou ateísmo. Porém ele funciona como o exemplo de que, já que estão todos os homens dotados dessa capacidade racional, não devem sob nenhuma hipótese guiarem-se simplesmente pela fé, já que cada um será julgado, e o critério para o julgamento são as suas obras, cujo prêmio ou castigo Ihes são diretamente proporcionais, muito diferente das noções de fidúcia e da percepção da graça dentro do Luteranismo. A ideologia em cena, ao enfocar a primazia das boas obras, direciona a atenção para o uso da liberdade individual. Don Juan é livre para mudar de rumo, e the são dados avisos que seriam um ensejo para essa mudança, mas, usando sua liberdade de maneira equivocada, assinala sua própria condenação.

Notamos, porém, que Don Juan tem a possibilidade de pecar porque nasceu provido da sindérese e do livre-arbítrio, ambos provenientes de Deus. Ora, mas por que, então, Deus concede o livre-arbítrio se este é que torna possível o pecado? 
Em O livre-arbítrio, Agostinho nos reponde que o homem, pensado em sua condição de homem, é um certo bem, e tanto ele quanto o Bem procedem de Deus ${ }^{8}$. Ninguém poderia proceder virtuosamente a não ser que assim o desejasse, e para isso é mister possuir a vontade livre. Se comprovamos que através da vontade livre abre-se a possibilidade do pecado, nem por isso devemos concluir que foi com esta finalidade que o criador a concedeu. Assim sendo, há razão suficiente para ela nos ser dada, pois sem ela não nos seria possível viver virtuosamente. Desta maneira, não há como considerar uma injustiça de Deus o fato de nos haver dotado de livre-arbítrio, com isso sujeitando-nos à possibilidade do erro. Da mesma forma que nossas mãos, pés e olhos são um bem, que grande falta fazem quando um não os possui, e que, porém, podem ser usados de maneira incorreta na prática do mal, assim o é o livre arbítrio: deve-se, sim, condenar os que o usam mal, mas nem por isso afirmar-se que não deveria dá-lo quem o deu. Deus é justo, confere prêmios aos bons e castigos aos maus, que são males para estes últimos. É autor deste tipo de "males", mas não do mal praticado por alguém, responsabilidade de seu autor, praticado por livre vontade. A liberdade, portanto, constitui um bem que nos fora dado para que Deus pudesse medir e regular o valor da nossa virtude. Isso significa que, sem ela, tudo teria o mesmo peso, sendo impossível, então, dimensionar cada ato como bom ou mau - o que certamente inviabilizaria a execução da justiça divina.

Agostinho traça uma espécie de divisão por ordem de grandeza dos bens de que a humanidade fora dotada. Considera como grandes bens as virtudes, pelas quais se vive honestamente, e das quais ninguém pode fazer mal uso. Dentre os bens médios, estão todas as potencialidades do espírito, sem as quais não é possível viver honestamente. Por último, nos bens ínfimos, estão as perfeições de quaisquer corpos, sem as quais é plenamente possível que se viva honestamente, já que a honestidade encontra-se no espírito. Os bens médios e ínfimos podem ser bem ou mal utilizados. Pensemos, mais uma vez, no exemplo supracitado, do uso das mãos (ínfimos) e da vontade (médio): as mãos, quando mal utilizadas, roubam; a vontade, nesse caso,

\footnotetext{
${ }^{8}$ AGOSTINHO. O livre-arbítrio. Braga: Faculdade de Filosofia, 1990. Edição de António Soares Pinheiro. pp. $79-80$.
} 
deseja roubar. Quando a vontade adere ao bem incomutável, que é o bem comum para todos e não privativo de cada um, então o homem encontra-se dentro da vida venturosa. Assim, embora seja um bem médio, a vontade alcança os maiores bens do homem, as virtudes. Porém, quando se distancia do bem comum e se volta para seu bem particular, ou para um bem exterior, ou inferior, comete-se o pecado, através do mal uso dessa mesma vontade. Além disso, defende que todo pecado consiste numa dominação do indivíduo pela lascívia, ou "iniância" cada um pode perder contra sua vontade. Aquele que tem a iniância de praticar o pecado é tão pecador quanto aquele que o pratica. Ou seja: o que caracteriza o pecado está sempre na vontade do homem, pois mesmo não exteriorizando o mal, não praticando o pecado, torna-se pecador pelo simples fato de sua vontade estar dominada pela paixão. Vemos o quanto isso se aplica, por exemplo, à insistência com que Don Juan demonstra desejar a propagação de seu nome, estando sua vontade dominada pelo apego mundano da fama: a simples existência desse desejo já seria um pecado, fato bastante agravado pelos subterfúgios que ele usa para realizá-lo. Para que possa evitar ser possuído pela iniância, o homem deve, antes, fazer uso da boavontade, que se define pela intenção se viver reta e dignamente, visando atingir a sapiência. ${ }^{10}$

Dominado pela paixão de enganar e de ver seu nome propagado como sendo o maior burlador de Espanha, Don Juan usa o livre-arbítrio em prol de seu bem particular. Todavia, ele não está destituído da sindérese católica, pois demonstra ter plena consciência da irregularidade de seus atos e - fator agravante - orgulha-se disso. Ou seja: embora dotado de capacidade para discernir o Bem e o Mal, deleita-se com desagradar "Deus e o mundo", o que neste caso é quase literal, contando, porém,

\footnotetext{
${ }^{9}$ Adota-se aqui o termo "iniância" conforme a tradução de António Soares Pinheiro consultada para este trabalho: "Iniância' deriva do verbo latino 'inhiare', também usado por Agostinho, o qual significa esperar ou desejar avidamente. Exprime qualquer das impulsividades sensitivas, geralmente desregradas, para 0 seu objecto, ou seja, o que vulgarmente se denomina 'paixões'". In AGOSTINHO. Op. cit., p. 29.

10 "A sapiência ou 'sabedoria' consistia no pretendido domínio de toda a ciência, e no conhecimento das supremas leis da moralidade, um e outro unidos ao perfeito exercício do conjunto das virtudes. O seu oposto era a insciência (stultitia), caracterizada pela ignorância e falta de princípios morais". Idem, Ibidem, p.36, nota 9.
} 
com Sua misericórdia no momento final. Morto pelas mãos de um enviado divino, sem sacramentos e sem justificação, só lhe resta o ardor infernal como prova de que o memento mori "no hay plazo que no llegue ni deuda que no se pague" estava certo. Da mesma forma, qualquer traço de fidúcia luterana também estava condenada a arder no fogo, do inferno ou da Inquisição: Don Juan Tenorio serviria também para lembrar ao público que, memento mori, agindo "pela fé somente", sem ater-se à legitimidade de seu comportamento, este seria certamente seu destino.

$E$ eis que a justiça é feita pelas mãos de uma estátua que é a representação legítima do divino: ela é a pedra, símbolo da perenidade do Reino de Deus. A estátua do comendador também encarna um paradoxo exemplar: ela representa o ideal de liberdade católico - o que pode parecer-nos muito estranho como atributo de uma figura pétrea. Lembremos, porém, que para o catolicismo a escolha de Deus já é a escolha da liberdade pois, sendo Ele infinitamente perfeito, é infinitamente livre. O fiel deve ter a liberdade de subordinar-se. Don Gonzalo de Ulloa, morto por Don Juan em combate na tentativa de guardar a honra de sua filha, sendo evidentemente o herói da sociedade retratada, representa a autoridade do Pai, Senhor, Deus. Diz seu epitáfio:

Aquí aguarda del Señor el más leal caballero la venganza de un traidor. ${ }^{11}$

A subordinação de Don Gonzalo foi recompensada por Deus, que lhe permitiu a justa vingança de sua morte. Nas palavras da estátua:

\footnotetext{
Las maravillas de Dios

son, Don Juan, investigables

y así quiere que tus culpas

a manos de un muerto pagues;
}

\footnotetext{
${ }^{11}$ MOLINA, Tirso de (atribuída a ). El burlador de Sevilla. Madrid: Ediciones Cátedra, 1990. Edición de Alfredo Rodríguez López-Vázquez, p. 213. Todas as citações extraídas da peça serão referenciadas, a partir deste ponto, apenas pelos números dos versos dessa edição.
} 
y así pagar de esta suerte

las doncellas que burlaste

Esta es justicia de Dios:

quién tal hace, que tal pague. ${ }^{12}$

É interessante notarmos nessa fala a afirmação de que "as maravilhas de Deus são investigáveis", pois ela retoma a idéia de que qualquer homem é capaz de perceber qual seja a Sua vontade. Esse discernimento refuta a idéia de predestinação luterana, segundo a qual não podemos perscrutar esse mistério, pois não nos é possível entendê-Lo, devido às limitações da razão humana. Mais uma vez temos a sindérese católica, seguida pelo mau uso do livre-arbítrio e o inevitável castigo. Há, novamente, a correspondência agostiniana entre a vontade que se afasta do bem comum em favor apenas do indivíduo e o castigo justo, aplicado a essa falta: "Esta é a justiça de Deus/ quem tal faz, que tal pague."

Numa outra abordagem, também podemos relacionar essa visão com a controvérsia teológica "de auxiliis", sobre a graça divina. De um lado da disputa estava o dominicano Domingo Báñez (1528-1604), que liderava a linha tomista (baseada na escolástica de São Tomás de Aquino), segundo a qual era necessário admitir a "premonição física", ou seja, admitir que tudo que se move é movido por outro, o que equivale a dizer que, em última instância, tudo é movido por Deus. Isso significa que qualquer obra humana é motivada por Ele. Pois bem: do outro lado da controvérsia estava o jesuíta Luis de Molina (1535-1600), quem deu nome ao molinismo, linha que considera que esse impulso a priori para a vontade humana desrespeita a liberdade desta. A essa afirmação, respondiam os tomistas que se Deus tivesse que esperar a livre ação do homem para só depois julgá-la, Ele estaria em alguma medida dependente e subordinado ao homem.

Passemos, então, ao problema da salvação: se Deus move as criaturas a obrar, qual o Seu papel no pecado humano? Para os tomistas, Deus nos dá a força de

\footnotetext{
${ }^{12}$ Versos 2839-2846
} 
obrar, que é um ser, mas o pecado é um não-ser, e para o não-ser não se necessita do concurso divino. ${ }^{13}$

Agora, se Deus não move as criaturas, conforme pregam os molinistas, Ele sabe, no entanto, desde a eternidade, quem vai salvar-se ou condenar-se. Ele escolhe ou condena os homens em perfeita simultaneidade com o bem ou mal obrar de cada um, o que não o torna dependente da ação humana: a ciência de Deus sobre o nosso destino (e, conseqüentemente, a predestinação) é estritamente simultânea às ações e à vida da criatura. Sob esse aspecto, podemos pensar que o autor de El burlador de Sevilla talvez fosse mais propenso à corrente molinista no que tange à ênfase que a obra dá à liberdade de escolha de cada um, no que ecoa também a concepção agostiniana de livre-arbítrio. É conveniente lembrarmos que foi convocada pelo Papa uma congregação especial para examinar a disputa, e que por várias ocasiões essa esteve prestes a condenar a doutrina de Molina, o que só não ocorreu porque, além de a Companhia de Jesus ser um instrumento importante para o papado - nas universidades e na expansão territorial do catolicismo - ela era, no fim das contas, mais eficiente no combate aos protestantes do que a dos dominicanos, que, de algum modo, dava margem a conceitos também usados por aqueles. A solução, então, foi permitir que cada grupo opinasse como quisesse, proibindo-os, porém, de tachar de hereges os seus contrários e também de publicar livros sobre o tema sem 0 consentimento do Santo Ofício. ${ }^{14}$

Podemos, assim, concluir que o autor de El burlador de Sevilla, em consonância com o pensamento agostiniano, e talvez tendo em vista a controvérsia sobre a graça de Deus, considera que todos os homens estão dotados da sindérese e do livre-arbítrio; a diferença entre Don Juan e Don Gonzalo é apenas de uso deste atributo, e não uma diferença originária, predestinada. Nisto, aproveita o ensejo para propagar ideais antiluteranos de tal modo que a estátua de Don Gonzalo alegoriza a

${ }^{13}$ MORÓN ARROYO, Ciriaco. La controversia "de auxiliis" (sobre la gracia). In MOLINA, Tirso. El condenado por desconfiado. Madrid: Ediciones Cátedra, 1992, p.34.

${ }^{14}$ Cf. AVILLÉS, VILLAS \& CREMADES. Historia de España: la crisis del siglo XVII bajo los últimos Áustrias (1598-1700). Madrid: Editorial Gredos, 1988, p. 199. 
própria Igreja Católica, encarnando as idéias contra-reformistas e dogmáticas freqüentemente presentes na produção teatral do Siglo de Oro.

\section{A IGREJA E O ESTADO: O CORPO MÍSTICO ESPANHOL.}

Veremos a partir deste ponto o modo como se articulam Estado e Igreja na sociedade espanhola do XVII, e de que forma essa relação simbiótica é caracterizada dentro da peça El burlador de Sevilla, notadamente através das personagens de Don Juan Tenorio e de Don Gonzalo de Ulloa.

\section{UMA SOCIEDADE CONTRA O INDIVÍDUO.}

De acordo com o crítico literário lan Watt, é possível estabelecer-se a seguinte relação entre Renascença e Reforma Protestante: ambas optam pela primazia do indivíduo sobre o coletivo, traço que seria definidor da moderna sociedade ocidental ${ }^{15}$. Também defende a tese de que o individualismo sempre foi germinal dentro doutrina cristã. Para tanto, baseia-se em Louis Dumont, que havia estudado a sociedade de castas indiana e o modo como esse sistema se opunha à forma social do cristianismo, pois, enquanto na primeira as pessoas tendem a aceitar a as coerções da família extensa, da casta e da religião, sendo reconhecidos como "indivíduos-nomundo", no cristianismo haveria uma sociedade teoricamente baseada na igualdade entre os fiéis, sendo reconhecidos como "indivíduos-relacionados-com-Deus"16. A união entre os crentes é de caráter meramente espiritual, sendo cada um deles uma unidade

\footnotetext{
${ }^{15}$ WATT, Ian P. Mitos do individualismo moderno: Fausto, Dom Quixote, Dom Juan, Robinson Crusoe. Rio de Janeiro: Jorge Zahar Editor, 1997, pp. 235-240.

${ }^{16}$ DUMONT, L. Essais sur l'individalisme: une perspective anthropologique sur l'ideologie moderne. Apud WATT. Op. cit., p.235.
} 
moralmente autônoma. Watt conclui então que a Reforma, ao reforçar a idéia de ligação direta entre Deus e o indivíduo, corrobora a afirmação do individualismo renascentista, principalmente na concepção de Calvino, cuja aplicação secular do protestantismo casou-se com o capitalismo individualista. ${ }^{17}$

Assim como esteve apartada do desenvolvimento do capitalismo financeiro, a Espanha também se afastou da Reforma Protestante, que no geral acompanhava a nova economia ${ }^{18}$. Aliás, não apenas se afastou como agiu ferozmente para deter o protestantismo através da Contra-Reforma. Assim, se podemos afirmar que Reforma e capitalismo enfatizam a autonomia do indivíduo, é passo inevitável concluirmos que na Espanha o indivíduo não teve a chance de se desenvolver no mesmo grau.

De fato, a sociedade espanhola do XVII se vê como corpo místico ${ }^{19}$, onde não pode haver o fomento do individualismo de qualquer um dos seus constituintes, pois é inerente à forma aristocrática de governo ver seus cidadãos como elos de uma

\footnotetext{
${ }^{17}$ WATT. Op. cit., p.236. A causa da relação entre o calvinismo e o capitalismo na visão de Max Weber não se baseia em uma descendência obrigatória: "Apesar de pouco importante numericamente na época de expansão do protestantismo, ele [calvinismo] era ligado em qualquer país a uma determinada classe social (como o eram aliás os demais ramos do protestantismo), de uma maneira tão característica, e, de certa forma, 'típica', que, por exemplo, nas igrejas dos huguenotes franceses, monges-industriais (comerciantes, artesãos) constituíam boa parte dos fiéis, especialmente na época das perseguições. Até os espanhóis sabiam que a heresia (dos calvinistas da Holanda) 'promove o comércio', e isso vem coincidir com as opiniões expressas por Sir William Petty, em sua discussão sobre as razões do desenvolvimento capitalista nos Países Baixos. Gothein corretamente qualifica a diáspora dos calvinistas como 'essência da economia capitalista'. Mesmo assim, todavia, poder-se-ia considerar como fator decisivo a superioridade das culturas econômicas francesa e holandesa, que deram origem a essa diáspora, ou, quem sabe, à imensa influência do exílio na decomposição das relações sociais tradicionais." WEBER, Max. A ética protestante e o espírito do capitalismo. Trad. Maria Irene Q. F Szmrecsányi e Tamás J. M. K. Szmrecsányi. São Paulo: Pioneira, 1967, pp.25-26.

${ }^{18}$ Como sabemos, a Espanha do século XVII — onde surge El burlador de Sevilla por volta de 1630 encontra-se já à beira do colapso de seu mercantilismo, que havia apostado apenas no exploração de metais americanos. Sua economia tornava-se cada vez mais dependente de importações, devido à falta de incentivos às atividades agrícolas e manufatureiras: como dispunha de muitos metais, além de não produzir, pagava o preço que Ihe fosse cobrado pelo que precisava. Já desestabilizada, a Espanha se colocava à margem da expansão capitalista.

19 A expressão corpus mysticum foi originalmente usada na época carolíngia como equivalente à Eucaristia ou à hóstia consagrada, assumindo mais tarde uma conotação sociológica, como quando o papa Bonifácio VIII, na bula Unam sanctam de 1302, define a Igreja como "um corpo místico cuja cabeça é Cristo". O termo foi facilmente adaptado por juristas e acadêmicos para a concepção e estabelecimento do Estado secular, também considerado corpo místico cuja cabeça seria o rei. Cf. KANTOROWICZ, E. H. Os dois corpos do rei: um estudo sobre teologia política medieval. São Paulo: Companhia das Letras, 1998, pp.125-169.
} 
cadeia, integrada por todos os membros da sociedade, desde o plebeu até o próprio rei. ${ }^{20}$

É nessa sociedade tão contrária ao indivíduo, portanto, que surge a personagem de Don Juan Tenorio. A peça El burlador de Sevilla contém claramente uma lição de moral, como todo o teatro religioso do Siglo de Oro. De fato, a personagem quer se destacar nessa sociedade através da fama de seu nome, como se ela pudesse "pairar" sobre todos os níveis, desobedecendo ao princípio de "não sair de seu devido lugar" que regia o corpo social. A fama que Don Juan almeja o eleva sobre todos os homens, independentemente da classe social. Ele promove uma espécie de "denúncia apologética" em que o intuito do autor é o de acusar quem se comporte como a personagem, ao mesmo tempo efetuando uma apologia da moralidade católica típica do teatro do Siglo de Oro. E Don Juan vai atacar precisamente o ponto frágil sobre o qual a sociedade espanhola do XVII se alicerça: a honra, que ele destruirá e de seus destroços construirá sua fama - conceito que, como veremos, distingue-se da honra por não ser necessariamente sinônimo de boa reputação como esta.

O desejo de fama tão característico da personagem em questão não constituiu, obviamente, nenhuma novidade quando da elaboração dessa obra. Iremos vasculhar os mais remotos registros históricos e literários que atestam sua existência, e que, devidamente contextualizados, nos ajudarão a delinear, por contraposições, a configuração desse desejo em El burlador de Sevilla.

\section{OS CONCEITOS DE GLORIA, HONOR E VIRTUS.}

É fundamental, antes de prosseguirmos, precisarmos os conceitos de glória, honra e virtude se quisermos analisar adequadamente a base moral sobre a qual se sustenta El burlador de Sevilla. Esses conceitos, que constumavam entremear-se na

${ }^{20}$ TOCQUEVILLE, A. L'Ancien Régime et la Révolution. Apud WATT. Op. cit., pp.238-239. 
literatura clássica, aparecem sob uma nova luz na obra, refletindo ideais religiosos e sociais típicos da Espanha do XVII.

Primeiramente, delimitaremos o que eram a gloria, a honor e a virtus entendidas inicialmente segundo os padrões clássicos. Esse resgate histórico nos ajudará a recompor, por contraposição, seu significado no momento de composição de El burlador de Sevilla - onde vemos Don Juan "tirar a honra das mulheres" enquanto Don Gonzalo encarna a glória que se pode almejar nesse universo, além de assistirmos a uma generalizada falta de virtude na maioria das personagens.

Sabemos que era traço comum da cultura grega antiga a atenção ao indivíduo, o desenvolvimento da personalidade e o desejo de perdurar na memória coletiva mesmo após a morte. As formas de manifestação desse anseio, segundo María Rosa Lida de Malkiel $^{21}$, se comprovam nas práticas do enterro público, do discurso panegírico, do epitáfio, dos retratos particulares, além da variedade de nomes próprios com a idéia de glória e excelência: Cleo-, -cles, -doxo, Aristo-. A estudiosa atribui a esse interesse pelo individual a criação de riquíssimos caracteres literários, com destaque para Aquiles, que ao se defrontar com os dois destinos possíveis previstos pela sua mãe, a deusa Tetis, escolhe aquele que encurtará sua vida terrena, fato que ele considera como um preço baixo a ser pago pela vida que se prolongará na glória de seu nome.

A fama almejada por Aquiles, não é uma fama qualquer, e sim aquela espécie que corresponde ao conceito clássico de gloria: o feito de ser considerado bom pelos homens de bem, e por isso ser imortalizado. De acordo com os estudos de Maria Helena da Rocha Pereira, a gloria "é o público reconhecimento das qualidades do cidadão"22, isto é, a conquista de uma boa reputação. Ultrapassa a idéia da mera fama, pois esta é apenas "o que se diz a respeito de alguém", sendo um termo neutro ${ }^{23}$,

${ }^{21}$ MALKIEL, María Rosa Lida. La idea de la fama en la Edad Media castellana. México: Fondo de Cultura Económica, 1983, p. 13.

${ }^{22}$ PEREIRA, Maria Helena da Rocha. Estudos de História da Cultura Clássica. Lisboa: Fundação Calouste Gulbenkian, 1998, p. 333.

${ }^{23}$ Distinção feita por EARL, D. C. The Moral and Political Tradition of Rome. Apud PEREIRA. Op. cit., p. 334 
enquanto a gloria prevê o bom valor do quê é dito, e de quem o diz. É também é um valor que se relaciona mais tarde à res publica romana, de caráter político e social, e que se reflete sobre a herança da estirpe. Em Cícero, são inúmeras as reflexões, espalhadas em diversos textos, sobre a natureza e o valor da gloria, geralmente relacionando-a com virtus, conceito que evolui de sua acepção original de cunho militar (traduzível por valentia, coragem) para um termo que se aproxima da "hombridade", sendo não só "homem", mas "homem correto", especificando-se mais adiante em sua evolução como "qualidades boas do caráter", já no sentido em que conhecemos atualmente: virtude. Podemos averigüar dita relação neste trecho de Dos Deveres: "A melhor das heranças que os pais podem deixar aos filhos, mais valiosa do que todo o patrimônio, é a gloria da sua virtus e dos seus feitos." ${ }^{24}$ Além disso, Cícero especifica que ela resulta de três condições: de ser amado pela multidão, de se possuir a confiança (fides) dessa multidão, e de ser admirado e merecedor de honrarias.

\footnotetext{
Em Cícero, apenas nalguns passos das Tusculanas e, sobretudo, no Sonho de Cipião, a glória é diminuída e mesmo reduzida a nada, na longa fala do Africano ao seu descendente por adopção. É aí que se exprime a noção de que é na própria virtus, e não no reconhecimento vindo dos outros, que está sua recompensa." ${ }^{25}$
}

O conceito de gloria não se relaciona somente com a virtus, mas também guarda íntimo contato com a honor, que assim como aquela faz referência ao reconhecimento público, ligado à vida política, do mérito que tem função pedagógica para a cidade. A honor, porém, é um degrau inferior à gloria, pois se atinge mais facilmente do que a imortalidade concedida por esta. Sendo assim, a honor é alcançada pelo vir honestus (aquele que é íntegro e digno de admiração, honorável), enquanto a gloria é apenas atribuível ao vir magnus. O vir honestus torna-se digno de honrarias e homenagens, que no entanto não garantirão sua posteridade gloriosa. A imortalidade, portanto, é somente atingível pelo vir magnus e através da gloria.

${ }^{24}$ Cícero. Dos Deveres. Apud: PEREIRA. Op. cit., p. 335.

${ }^{25}$ PEREIRA. Op. cit., p. 336. 
Embora Cícero, como já foi dito, algumas vezes defenda a prioridade da virtus, no geral se mantém dentro de uma linha latina que encara positivamente o desejo de gloria, da qual fazem parte Salústio, Horácio e Ovídio, dentre outros. É digno de nota aqui o caso de Salústio, que chega até mesmo a prescindir de uma defesa do desejo de gloria, partindo do pressuposto de que este é natural a qualquer indivíduo, idéia presente em Conjuração de Catilina e em Guerra de Yugurta. Nas palavras de Lida de Malkiel:

\begin{abstract}
Salustio ni expresa el valor de la gloria, y se refiere a su empeño por ganarla como un moderno hablaría del instinto de conservación. Porque su deseo raya casi en lo biológico, la gloria es meta común de buenos y malos, quienes difieren únicamente en el proceder que adoptan para alcanzarla (...) El autor puede cargar la memoria de Catilina con toda suerte de crímenes; no por ello dejará éste de tentar a los conjurados con la gloria que, entre otros bienes, se les seguirá de su golpe de estado. ${ }^{26}$
\end{abstract}

Ou seja, no caso de Salústio parece haver um distanciamento entre as qualidades intrínsecas ao homem (virtus) e o reconhecimento público. Ainda que usando métodos reprováveis, importa mais a imagem final de grande homem (vir magnus) que chegará à "platéia" de cidadãos, garantindo sua posteridade.

Essa linha romana de defesa do desejo de gloria, no entanto, não foi uniforme ao longo da história da República e do Império. O caso mais notável de voz dissonante encontra-se em Virgílio, e sob este aspecto é ponto pacífico entre a crítica considerá-lo como avesso à busca superficial pela fama. De acordo com Pereira ${ }^{27}$, a ideologia da Eneida sobrepõe a virtude à glória, e Lida de Malkiel encontra provas desse interesse secundário pela fama ao comparar o comportamento dos guerreiros da Eneida ao "ingenuo deseo de sobresalir por el que marchan a la batalla Glauco y Aquileo."28 $\mathrm{O}$ desejo de glória que não se liga a nenhuma vantagem prática configurase em Virgílio como uma espécie de futilidade juvenil, presente em mancebos, como Niso, Euríalo, Palante e Ascânio. Para concluir, "hasta parecería que Virgilio juzga

${ }^{26}$ MALKIEL. Op. cit., p.33.

${ }^{27}$ PEREIRA. Op. cit., p.336.

${ }^{28}$ MALKIEL. Op. cit., p.37. 
semejante deseo como frivolidad griega, no tolerable en la acción verdadera, sino, a lo sumo, en el deporte, en los remeros que esperan palpitantes la señal de la regata (Eneida, V, 137-138)." ${ }^{29}$

Porém, uma voz dissonante muito mais poderosa viria não só a contraporse ao romano desejo de gloria, mas a impor-se, com o advento do Cristianismo, ao qual o imperador Constantino se declara convertido em 312: a glória cristã não depende de um julgamento dos homens, como aquela até então conhecida, e sim da misericórdia divina. Obviamente não se alteraram os modos de senti-la repentina e massivamente, mas já não era possível ignorar o pouco apreço tido pelo desejo de fama na nova instituição.

É em nome da glória de Deus que falam as mais relevantes vozes da Igreja medieval. Santo Agostinho, em A cidade de Deus ${ }^{30}$, debate a importância da idéia de fama e seus atrativos no mundo pagão, chegando, em linhas gerais, à conclusão de que o homem de virtude irreprimível não precisa do alento propiciado pela glória mundana e dispensa os juízos dos que lhe engrandecem, porém, com o fito de ajudálos, os induz a louvar o Único digno de louvor. Assim sendo, também conclui que não se pode subordinar a virtude à fama (o que ocorria em Salústio).

Apesar da distância cronológica, é possível verificarmos uma linha contínua do pensamento agostiniano que chega até Santo Tomás de Aquino. Este não chega nem mesmo a citar a fama póstuma, diferentemente de Agostinho, que seria uma substituta da imortalidade, ocupando-se exclusivamente da inanis gloria, o desejo de glória terrena:

Más desapasionado que San Agustín y otros Padres de la Iglesia (San Juan Crisóstomo, San Gregorio Magno), no condena redondamente el sentimiento de la fama y admite que, sin ser un bien en si, puede serlo accidentalmente (Summa theologica, Secunda secundae, quaestio CXXXII, art. I) (...) pero inmediatamente viene la necesaria aclaración: (...) sin ser pecado mortal, es el amor a la gloria pecado peligroso, pues predispone al hombre a olvidar el verdadero fin de sus buenas acciones. ${ }^{31}$

\footnotetext{
${ }^{29}$ Idem, Ibidem, p.38.

${ }^{30}$ AGOSTINHO. A cidade de Deus. Apud MALKIEL. Op. cit. p.101-103.

${ }^{31}$ MALKIEL. Op. cit. p.103.
} 
Vimos aqui, resumidamente, o que veio a ser a posição da Igreja perante a questão do desejo de glória humana: um esquecimento da verdadeira glória, que só pode provir da graça de Deus. A conclusão à qual pudemos chegar até o momento é a de que a noção de glória terrena implica necessariamente uma concepção individualista da existência. A fama exclui a priori a noção de rebanho, de igualdade natural entre os homens, tão fundamental no Cristianismo. Também se opõe às sociedades medievais, que se viam como "corpo místico" - idéia que, porém, persiste em sistemas absolutistas, como a Espanha retratada em El burlador de Sevilla -, onde cada uma das camadas sociais ordenadas hierarquicamente se articulam como num corpo vivo, estando o rei no topo, no lugar da cabeça. Esse corpo, da mesma forma que não permite que "um pé" passe a ocupar um lugar de "braço", não prevê que cada uma das partes tenha autonomia, que possa sobreviver fora de seu lugar "natural": o indivíduo destacado simplesmente não pode existir. Isso nos leva a pensar que a idéia de fama perderia posição nessas sociedades, pois o desejo manifesto dela poderia ser identificado como uma espécie de rebelião ou heresia. No entanto, é claro que a fama alcançada por alguém dentro de um regime absolutista pode ser de grande serventia, já que pode propiciar-lhe mais oportunidades para favores, concessões e honrarias - 0 que, aliás, é um traço que persiste entre nós: a fama é uma garantia de proteção. Notemos, entretanto, que essa proteção só está assegurada quando se tem uma fama positiva, uma boa reputação: a chamada honra. A fama que o burlador busca certamente não é desse tipo, e isso é algo preocupante para seu pai: "Verte más cuerdo quería / más bueno y con mejor fama." ${ }^{32}$

Mas notamos que Don Juan não só quer a propagação de seu nome, como quer que ela aconteça devido a um único movimento repetitivo seu, o de enganar todos à sua volta para desonrar uma mulher:

Sevilla a voces me llama el Burlador, y el mayor gusto que en mí puede haber es burlar una mujer

${ }^{32}$ Versos $1416-1417$ 
y dejarla sin honor. ${ }^{33}$

A honra era um dos valores fundamentais na Espanha do XVII. Sua característica mais relevante é a de que só pode existir pela opinião dos demais sobre determinado homem. A honra é sempre externa, é a opinião dos outros homens que prevalece, e nisso se distancia da honor, outro termo usado na época, que se relacionava com a idéia de "dignidade", de consciência tranqüila consigo mesmo, sem se pautar pelos demais. Muitos autores, porém, usam indistintamente ambos os termos, como no trecho supracitado, onde honor se usa na acepção de honra. Esta, pertencendo à esfera social, também tinha uma dimensão diacrônica, que a ligava à linhagem familiar da pessoa, e uma dimensão sincrônica, que seria o bom nome que liga a pessoa à sua comunidade: alguém "desonrado" desonra também sua família e sua cidade. Sob esse aspecto, a honra espanhola se liga à honor clássica, no sentido de que as duas zelam pela boa reputação de alguém como reconhecimento público de suas qualidades. O hombre honrado equivaleria ao vir honestus no sentido de que ambos têm uma função pedagógica para a cidade - como veremos, Don Gonzalo, o convidado de pedra, era o único homem verdadeiramente honrado naquele universo. É claro que, apesar de ser um guardião da honra, Don Gonzalo não aspirava à glória de seu nome, pois, seguindo a teologia de Santo Agostinho, o único digno de louvor é Deus ${ }^{34}$.

Essa honra de caráter coletivo progressivamente se transformou na honra depositada na mulher, que passou a ser a portadora da honra dos homens da família, especialmente o pai e o marido. Podemos percebê-lo na réplica do rei de Castilla ao descobrir a traição de Isabela:

¡Ah, pobre honor! Si eres alma del hombre, ¿por qué te dejan en la mujer inconstante,

${ }^{33}$ Versos 1305-1309.

${ }^{34}$ AGOSTINHO. A cidade de Deus. Apud LIDA DE MALKIEL, María Rosa. Op. cit., pp.101-103. 
si es la misma ligereza? ${ }^{35}$

É essa honra, portanto, que Don Juan quer tomar para si: ao fazê-lo, ele toma também a honra dos homens da cidade, acumulando-a toda. O que era boa reputação alheia torna-se "a reputação" de Don Juan, que deseja ser conhecido como "el burlador de España" (com destaque para o artigo definido, que o destaca inclusive de outros patifes, como o marquês de la Mota):

\section{Catalinón:}

$Y$ tú señor eres langosta de la mujeres; y con público pregón, porque de ti se guardara cuando a noticia viniera de la que doncella fuera, fuera bien se pregonara: "Guárdense todos de un hombre que a las mujeres engaña, y es el burlador de España."

\section{Don Juan:}

Tú me has dado gentil nombre. ${ }^{36}$

O tema da honra era um dos preferidos pelo teatro do Siglo de oro, por considerar-se que, além de agradar, move o público a praticar o bem, como vemos na mais importante preceptiva dramática do período, Arte nuevo de hacer comedias, de Lope de Vega:

Los casos de la honra son los mejores porque mueven con fuerza a toda gente, con ellos las acciones virtuosas, que la virtud en dondequiera amada. ${ }^{37}$

\footnotetext{
${ }^{35}$ Versos 153-156.

${ }^{36}$ Versos 1471-1481.

${ }^{37}$ LOPE DE VEGA. Arte nuevo de hacer comedias. Edición de Enrique García Santo-Tomás. Madrid, Cátedra. Versos 327-330.
} 
Roubar a honra alheia para si através do engano significa que Don Juan nunca está dizendo a verdade, não tem compromisso com a palavra empenhada. No entanto, é a sua preocupação em cumprir com a palavra que dera à estátua do comendador Don Gonzalo, a de comparecer à segunda ceia, que acarreta sua punição. Segundo lan Watt:

\begin{abstract}
É verdade que Dom Juan ainda guarda uma residual e ambígua fidelidade ao código de honra, mas a sua versão desse código é muito mais arcaica e individualista do que as leis da cavalaria cristã. Para ele, o que está fundamentalmente em causa é a determinação de manter sua conduta pública, e não permitir que nada se diga ou se faça para deslustrar o mérito dessa face externa. E essa versão da honra, o pundonor, transforma-se no instrumento que dará morte a Dom Juan. Procurando certificar-ser de que Dom Juan comparecerá à segunda ceia, a estátua do Comendador o desafia: 'Como um cavalheiro, manterá sua palavra?' E ele responde: 'Sendo um cavalheiro, mantenho a palavra que dou aos homens'. Na segunda ceia é um aperto de mão - gesto cavalheiresco com o qual se sela um compromisso - o instrumento da danação de Dom Juan. $\mathrm{Na}$ verdade, a estátua alcança seu propósito valendo-se da pública sujeição de Dom Juan à noção individual e pagã de 'fidelidade' (troth), oposta à concepção cristã mais moderna e mais universal - corporificada na palavra 'verdade' (truth). ${ }^{38}$
\end{abstract}

Dessa forma, podemos concluir que Don Juan, ao corresponder "cavalheiramente" ao convite da estátua, não está tão preocupado com a fides, a palavra empenhada no acordo, e sim em preservar sua reputação de burlador destemido, que não conhecia limites. Aparentemente, o que ele pretende é ainda garantir a sua imagem pública, de quem desafiaria até mesmo o além-túmulo. Porém o confronto com a estátua do comendador - legítimo representante do homem honrado, e posteriormente do pai ofendido e assassinado - é o único limite possível à natureza sem limitações de Don Juan: a estátua de pedra, como representação do valor moral e religioso - já que a pedra é um símbolo que remete à Igreja, como nas palavras de Jesus: "Também eu te digo que tu és Pedro, e sobre essa pedra edificarei a minha igreja, e as portas do inferno não prevalecerão contra ela"39 —, exerce a justiça divina, já que a humana não o alcança.

${ }^{38}$ WATT, I. Op. cit., p.116.

${ }^{39}$ Mateus: 16:19. BÍBLIA SAGRADA. Trad. João Ferreira de Almeida. São Paulo: Sociedade Bíblica do Brasil, 1993. 
A conclusão que nos resta, então, é a de que o próprio desejo de fama por parte de Don Juan concorre para sua condenação. Don Gonzalo, que não era indivíduo, senão um homem honrado que era "homem do rei", "comendador de uma ordem religiosa", e "pai", ou seja, que só se definia por papéis sociais de prestígio moral, é a única personagem em toda peça moralmente inatacável - pois mesmo as mulheres "vítimas" de Don Juan tinham sua grande parcela de culpa - e o fato de voltar do além o investe ainda mais da autoridade de Deus, que age através dele. O corpo místico da sociedade espanhola, investido dos poderes pelo Senhor concedidos, vencera: conseguira matar o indivíduo.

\section{AS LEIS DESTE MUNDO}

Há um agravante no comportamento de Don Juan, por se tratar de um nobre: nessa posição ele ofende mais diretamente ao rei, já que está mais próximo à ele do que um plebeu. Da mesma forma, são gravíssimas as traições da duquesa Isabela, que teve a ousadia de convidar o amante para seus aposentos no palácio do rei de Nápoles, e de Don Pedro, homem de confiança do mesmo rei e tio de Don Juan que o ajuda a escapar quando descoberto por Isabela. O crítico John Varey nota que o autor da peça não chega exatamente a condenar o uso de favoritos por parte do rei, mas sugere que este abdica de parte de seu poder ao confiar em outros homens, já que a confiança pode estar dirigida a alguém tão digno como Don Gonzalo (o justo vingador de Don Juan), ou tão indigno como Don Pedro:

\footnotetext{
A través de la obra vemos que la administración de la justicia es corrupta, ineficiente y, hasta la escena final, claramente injusta. La gente del pueblo se da cuenta, antes que el Rey de Castilla, de que la Corte ha perdido contacto con la realidad y que 'la desvergüenza en España / se ha hecho caballería' (III, 131-32). Por obvias razones, Tirso carga al rey napolitano con más culpa que al de Castilla, pero, a pesar de esto, el público tuvo que darse cuenta de que la obra contenía un ataque agudo contra el poder de
} 
favoritos indignos, y una súplica para que la Corona interviniera más directamente en la administración de la justicia. No hubiese sido difícil referir esta lección moral a la España de Lerma y de Olivares. ${ }^{40}$

Desse modo, vemos uma clara referência na peça à presença dos validos no governo espanhol, cuja arbitrariedade e liberdade de ação incomodam a muitos, que os vêm como usurpadores do poder real. Durante o provável período de escrita de El burlador de Sevilla, em pleno reinado de Felipe IV (1621-1665), encontrava-se ao lado deste a figura marcante do Conde-Duque de Olivares (Gaspar de Guzmán, conde de Olivares e, após 1625, duque de Sanlúcar la Mayor), cujo mandato perdurou por vinte e um anos, de 1622 a 1643.

Diferentemente de seu antecessor mais notório, o Duque de Lerma (Don Francisco Gómez de Sandoval y Rojas, Marquês de Denia) ${ }^{41}$, valido de Felipe III (15981621), o Conde-Duque de Olivares rodeou-se de especialistas, tendo assessoria em todos os assuntos de Estado. Por outro lado, assim como o Duque de Lerma, Olivares também colocou familiares e amigos em pontos estratégicos, assegurando sua influência em diversos âmbitos do poder. Além disso, passa a atuar, juntamente com Felipe IV, de forma contrária e independente das decisões tomadas pelo Conselho de Estado, órgão de função consultiva e executiva na época de Felipe III, convertido em mero apêndice do governo. Como podemos ver, o poder ilimitado conferido ao valido tende a angariar muitas antipatias, já que tende a quebrar a unidade harmônica do corpo místico, igualando-se muitas vezes ao rei em funções que deveriam ser somente atribuíveis a este. A maioria dos autores espanhóis do XVII que trataram da figura do valido e dos demais favoritos do rei, mostram-se, no entanto, favoráveis à existência dos mesmos, defendendo somente uma redução dos seus poderes, para que não se igualem ao mando real. Assim encontramos em Quevedo:

\footnotetext{
${ }^{40}$ VAREY, John. Op. cit., p.146.

${ }^{41}$ O Duque de Lerma foi deposto em 1618 e substituído por seu filho, o Duque de Uceda, que para garantir sua eleição ao cargo, demonstrou uma profunda inimizade com o pai. Governou por apenas três anos, sob a pressão de Baltasar de Zúñiga, opositor de seu pai, e que preparava a introdução do futuro valido, seu sobrinho, o Conde-Duque de Olivares. Cf. AVILLÉS, VILLAS \& CREMADES. Op. cit., p. 50.
} 
Señor: criados han de tener los reyes, unos más cercanos de su persona que otros, y la voluntad no será en todos igual y determinará con más afecto en algunos; y entre ellos podrá ser que uno solo sea dueño de la voluntad del Príncipe (...) no está en eso el inconveniente si el rey sabe en qué cosas puede hacer a su criado dueño de su voluntad, y el criado cómo ha de usar de este favor y estado. ${ }^{42}$

Em El Burlador de Sevilla, os favoritos só são considerados indignos porque, assim como Don Juan, agem contrariamente ao princípio de articulação das partes pois, ao enganarem o rei, impedem que a justiça desse seja efetuada com sucesso. Relacionando a noção de corpo místico com o apontado por Varey, vemos que não há a condenação de favoritos pois estes seriam "o pescoço", a articulação necessária à ação real - mas digamos que esse sofreu um torcicolo e se recusa a obedecer os comandos da cabeça. A sociedade espanhola retratada em El burlador de Sevilla só consegue funcionar bem quando as partes se mantêm obedientes, articulando-se entre si com o intuito de promover a glória de Deus através do bom governo dos homens. Nesse sentido, Don Juan é um impedimento ao bom governo tanto quanto Don Pedro ou a duquesa Isabela, mas dá um passo além no quesito de justiça de divina, a qual ele também pensa poder enganar ao pedir perdão na hora da morte - sem atentar ao "fato" de que a justiça humana pode ser falível, mas a de Deus não.

"iTan largo me lo fiáis!" ("tenho tempo de sobra") - eis o refrão constantemente proferido por Don Juan Tenorio. Mas, afinal, o que significaria para a personagem "ter tempo de sobra"? Outro tema recorrente, na voz de outras personagens, e que se contrapõe ao dito anterior, nos ensina que "não há prazo que não chegue, nem dívida que não se pague". Existe um prazo depois do qual Don Juan simplesmente não pode voltar atrás: não se apagam os seus pecados e eles pesam enormemente sobre ele - suas obras o danam, sem espaço para o arrependimento ou salvação.

${ }_{42}$ QUEVEDO, Francisco. Política de Dios y gobierno de Cristo. Apud TOMÁS Y VALIENTE, Francisco. Los validos en la monarquía española del siglo XVII. Madrid: Siglo veintiuno de España editores, 1990, p.50. 
A personagem é a própria transgressão corporificada - sua ausência de limitações em todos os níveis (moral, espacial, temporal) dão a idéia de um poder demoníaco. Mas ninguém se iluda: Don Juan não é um revolucionário, um livrepensador que se rebelou contra o status quo. Embora se afaste substancialmente dos valores em questão, não os coloca em dúvida em nenhum momento; ele não é um rebelde. No fundo, instaura o caos, desarticulando a sociedade a seu redor na prática, mas não há reflexão ou discursos teóricos sobre seus atos. Quando há reflexão, esta vem sempre do "outro lado", e então vemos outras personagens (Catalinón, o comendador, o rei, o pai) tecendo discursos moralizantes. Mas Don Juan em nenhuma fala se mostra indignado quanto a essa moralidade. Podemos ver, ao longo da peça, que nas ocasiões que podemos considerar como oportunas a um questionamento da organização dessa sociedade, se isenta de fazê-lo: seu comportamento vai sempre no sentido de ignorar deliberadamente as restrições que se imponham à sua vontade, mas sem dar-se ao trabalho de contestá-las. Temos um exemplo dessa aparente indiferença de Don Juan com relação à ordem social quando o Marquês de la Mota confessa-lhe estar interessado em sua prima, Doña Ana, já que ele tanto é capaz de aconselhá-lo que se casem, como também que a engane:

\section{Don Juan:}

¿Es hermosa?

\section{Mota:}

Es extremada, porque en Doña Ana de Ulloa se extremó Naturaleza.

\section{Don Juan:}

¿Tan bella es esa mujer?

¡Vive Dios que la he de ver!

Mota:

Veréis la mayor belleza que los ojos del sol ven. 


\section{Don Juan:}

Casaos, si es tan extremada.

\section{Mota:}

El rey la tiene casada y no se sabe con quién.

\section{Don Juan:}

¿No os favorece?

Mota:

Y me escribe

\section{Don Juan:}

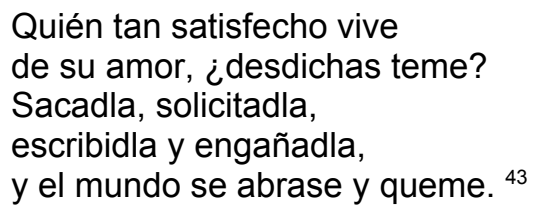

É interessante notarmos que aparentemente Don Juan não é contrário ao casamento legal. Pelo menos é essa a interpretação do Marquês ao responder-lhe que não podem unir-se porque o rei já designou a Doña Ana um outro marido. Mota parece não se dar conta de que Don Juan está referindo-se a um outro tipo de casamento do qual ele tampouco pretende cumprir a promessa: aquele que se consuma na relação sexual que se segue à simples troca de palavra de compromisso entre os amantes, prática oficialmente reconhecida como legítima pela Igreja Católica a partir do século XII com o Papa Alexandre III (em 1163), segundo o qual, se um voto de casamento é pronunciado no momento presente, ou se é feito como um projeção para o futuro, e se desse voto se segue uma consumação carnal, há uma união legal. O reconhecimento papal ecoa uma doutrina anterior, encontrável no pensamento de Graciano, quem, como bem mostra Bloch, defende o reconhecimento desse tipo de união:

\footnotetext{
${ }^{43}$ Versos 1259-1277.
} 
Aqui [em Graciano] o modelo invocado é o do sacramento: a união de Cristo com a Igreja, que, aplicada à esfera matrimonial, não está completa se não houver tanto livre escolha quanto unitas carnis física (união da carne). $\mathrm{Na}$ realidade, o que Graciano queria dizer não era que o consentimento não constituísse um casamento, uma vez que ele declara explicitamente que 'o consentimento daqueles entre os quais é feito o casamento é suficiente de acordo com a lei', mas que o vínculo só se tornava indissolúvel uma vez ocorrida a commixtio sexuum (consumação). Para Graciano havia uma diferença entre um vínculo válido e um inteiramente lícito, diferença esta que está na distinção entre as núpcias (conjugium initiatum) e sua confirmação no conjugium consummatum ou ratum. Somente com a união da carne é que o contrato se transforma num laço cuja condição sacramental não pode ser revogada. ${ }^{44}$

Assim, vemos em El burlador de Sevilla que a pescadora Tisbea, por exemplo, não adianta seu corpo como um meio de sedução, e sim como uma parte daquilo que é necessário para o reconhecimento de um casamento. Podemos comprovar que não se entrega de forma ingênua, pois o que quer é ter o direito de reclamar o casamento, oficializando-o. Ao descobrir-se abandonada, imediatamente lembra-se de que pode vingar-se de Don Juan, denunciando-o ao rei:

Seguidle todos, seguidle mas no importa que se vaya, que en la presencia del Rey tengo de pedir venganza:

¡Fuego, zagales, fuego, agua, agua,

Amor, clemencia, que se abrasa el alma! ${ }^{45}$

Além disso, também pretende remediar seu estado casando-se com Anfriso, alegando, ao encontrar-se por acaso com a duquesa Isabela, haver pensado que estava em seus braços quando se entregou na cabana a Don Juan, ou seja, alegará uma falsa intenção na consumação sexual para validar essa união:

Que me llevéis os ruego

con vos, señora, a mí y a un viejo padre,

${ }^{44} \mathrm{BLOCH}$, R. Howard. Misoginia medieval e a invenção do amor romântico ocidental. Tradução de Claudia Moraes. Rio de Janeiro: Editora 34, 1995, p. 226.

${ }^{45}$ Versos 1026-1031. 
porque de aqueste fuego

la venganza me dé que más me cuadre,

$y$ al Rey pida justicia

de este engaño y traición, de esta malicia.

Anfriso, en cuyos brazos

me pensé ver en tálamo dichoso,

dándole eternos lazos, conmigo ha de ir,

que quiere ser mi esposo. ${ }^{46}$

A duquesa Isabela parece usar da mesma estratégia, pois também demonstra esperar o cumprimento da promessa de casamento:

\section{Don Juan:}

Duquesa, de nuevo os juro de cumplir el dulce sí

\section{Isabela:}

Mi gloria, ¿serán verdades promesas y ofrecimientos, regalos y cumplimientos, voluntades y amistades ${ }^{47}$

Além disso, demonstra a mesma preocupação em remediar seu erro com outro casamento, exatamente como Tisbea:

Mi culpa

no hay disculpa que la venza.

[Aparte]

(Mas no será el yerro tanto

si el Duque Octavio lo enmienda. $)^{48}$

Arminta, por sua vez, mostra-se um pouco relutante em aceitar de imediato o discurso de Don Juan, que aparentemente a convence com base na lei que permitiria a anulação de seu casamento com Batricio, já que não havia ocorrido a consumação sexual:

${ }^{46}$ Versos 2250-2259.

${ }^{47}$ Versos 3-8.

${ }^{48}$ Versos 187-190. 


\section{Arminta:}

No sé qué diga,

que se encubren tus verdades

con retóricas mentiras.

Porque si estoy desposada, como es cosa conocida, con Batricio, el matrimonio

no se absuelve, aunque él desista.

\section{Don Juan:}

En no siendo consumado, por engaño o por malicia, puede anularse.

\section{Arminta:}

Es verdad.

Mas, jay Dios! que no querría

que me dejases burlada

cuando mi esposo me quitas. ${ }^{49}$

Já no caso de Doña Ana, a entrega do corpo parece ter um outro sentido, pois dá indícios de que quer apenas dar prova de seu amor ao primo, como vemos em seu bilhete interceptado por Don Juan:

\footnotetext{
Dice así: "Mi padre infiel en secreto me ha casado sin poderme resistir; no sé si podré vivir porque la muerte me ha dado. Si estimas, como es razón, mi amor y mi voluntad, y si tu amor fue verdad, muéstralo en esta ocasión. Porque veas que te estimo ven esta noche a la puerta, que estará a las once abierta, donde tu esperanza, primo, goces, y el fin de tu amor." ${ }^{50}$
}

${ }^{49}$ Versos 2093-2105.

${ }^{50}$ Versos: 1317-1330. 
Não temos indícios para saber se Doña Ana não arranjaria algum estratagema para que a vissem na calada da noite recebendo seu amado - o que certamente a livraria do casamento forçado pelo pai, e de sobra the traria o homem desejado. Contudo, se tinha ou não intenção de fazê-lo, não importa muito à moralidade da obra, pois é o seu ato de desobediência, por si só, que acarreta a morte de seu pai.

Por outro lado, claro está que a questão do livre consentimento e da consumação carnal como dados suficientes para a legitimidade da união não necessariamente era um pressuposto para todos. A aristocracia presente em El burlador de Sevilla casa-se, é claro, por outros interesses, como no casamento arranjado pelo rei para Doña Ana, ou como podemos entrever na resposta dada pelo duque Octavio a seu criado Ripio:

\section{Ripio:}

Pues, ¿no seré majadero, y de solar conocido, si pierdo yo mi sentido por quién me quiere y la quiero?

Si ella a ti no te quisiera fuera bien el porfialla, regalalla y adoralla, y aguardar que se rindiera. Mas, si los dos os queréis con una misma igualdad, dime, ¿hay más dificultad de que luego os deposéis?

\section{Octavio:}

Eso fuera, necio, a ser de lacayo o lavandera la boda. ${ }^{51}$

Como podemos ver, persiste aqui uma noção que separa radicalmente amor e casamento quando os envolvidos estão muito longe de ser "lacayo o

\footnotetext{
${ }^{51}$ Versos: $219-232$.
} 
lavandera"52. Don Juan, por sua parte, ao aconselhar o Marquês a casar-se e, imediatamente depois, a enganar Isabela, não é na verdade nem favorável nem contrário ao casamento: ele é simplesmente maquiavélico, no sentido de que considera válida qualquer estratégia que La Mota utilize para ter a mulher desejada.

Ainda vemos que Don Juan, no que tange à sua posição frente as restrições sociais, tampouco contesta a determinação real de ser "desterrado" em Lebrija, comunicada por seu pai. Não cabe pensar que haveria lugar de se fazer um discurso, proclamando a liberdade do indivíduo, cuja vontade não pode subordinar-se a uma resolução real, a qual ele não contradiz mas, obviamente, a desobedece:

\section{Don Juan:}

¿Por qué vienes de esa suerte?

\section{Tenorio:}

Por tu trato y tus locuras.

Al fin el Rey me ha mandado que te eche de la ciudad, porque está de una maldad con justa causa indignado (...)

Mira que aunque al parecer Dios te consiente y aguarda, tu castigo no se tarda, y que castigo ha de haber para los que profanáis su nombre, y que es juez fuerte Dios en la muerte.

\section{Don Juan:}

¿En la muerte?

¿Tan largo me lo fiáis? De aquí allá hay larga jornada.

\section{Tenorio:}

Breve te ha de parecer.

\section{Don Juan:}

Y la que tengo de hacer, pues a su Alteza le agrada,

\footnotetext{
${ }^{52}$ A separação radical entre amor e casamento é uma tópica do discurso do amor cortês. Cf. BLOCH, R. H. Op. cit.
} 
agora, ¿es larga también $?^{53}$

De qualquer forma, podemos ver que o que faz Don Juan é usar a estrutura social a seu favor, já que, não se opondo a nenhuma de suas instituições, aproveita-se das mesmas, utilizando-as a seu bel-prazer. Assim, sem proferir uma palavra sequer contra o casamento, usa a palavra empenhada e a consumação carnal, signos do matrimônio, para não efetivá-lo. Sem opor-se ao desterro, aproveita a "viagem" para seduzir mais uma mulher. Don Juan sente-se protegido, e não ameaçado, por essa estrutura social. E ele tem razões para isso, já que é de uma família de privados do rei de Castilla, como orgulha-se de dizer:

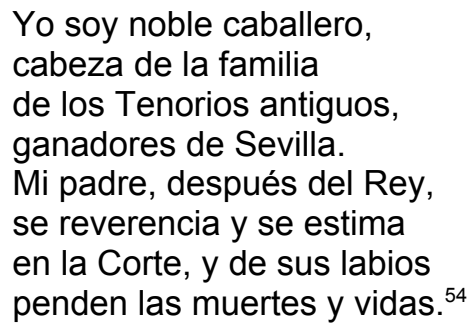

Essa proteção social evidencia-se quando se dirige a Catalinón:

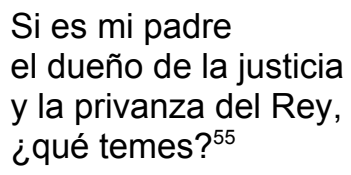

O sistema protege Don Juan; o uso que faz de sua condição nobre para humilhar - como o faz com Batricio, desrespeitando o direito deste sobre Arminta - e para resguardar-se, conforme the convenha, certamente é algo previsível nessa estrutura. Esse uso arbitrário da superioridade social é decorrente de uma hierarquização rígida, que é aceita por todos, caso contrário a manipulação de Don

\footnotetext{
${ }^{53}$ Versos 1421-1442.

${ }^{54}$ Versos 2066-2073.

${ }^{55}$ Versos 1994-1997.
} 
Juan não funcionaria. Porém ele ultrapassa o limite do aceitável — que não é apenas aceitável, e sim, como já dissemos, previsível, já que uma sociedade cujos poderes estão baseados no favoritismo prevê que alguém mais poderoso esteja fora do alcance da lei - cometendo também o pecado da hybris. Quando se considera numa condição superior aos demais homens, ele não está enganado, pois, de fato, ele pode usar sua condição social para isso, além de poder considerar-se um afortunado trickster - tipo popular do embusteiro - , já que suas burlas atingem até mesmo o rei. Sua desmedida encontra-se no fato de desejar equiparar-se ao divino, ou seja, é hybris comportamento desmedido, excessivo, que não condiz à condição de homem que conhece seu exato tamanho frente aos deuses -, desacatar a estátua de Don Gonzalo. É no contato com o elemento divino que a lição de moral "transcendente" se desvela. Somente no âmbito desse embate é que podemos interpretar Don Juan como personagem demoníaca, pois é quando evidencia-se sua construção alegorizante, personificação da vaidade tola dos homens - que em seu caso é a vaidade da fama, da conquista e do engano. Sobre as características dessa construção alegórica, trataremos no próximo capítulo. 


\section{CAPÍTULO 2}

\section{UMA CONSTRUÇÃO ALEGÓRICA}

Com base no que foi exposto no capítulo precedente, podemos formular a hipótese de que o objetivo de exemplaridade acaba por forçar-nos a uma interpretação alegórica de Don Juan Tenorio e das demais personagens de El burlador de Sevilla a alegoria, aqui, é entendida no sentido estrito de personificação de abstrações. Isto porque, para lograr a transmissão do ensinamento, todos eles têm que ser expostos da maneira mais simplificada possível, sem espaço para ambigüidades - pois, de qualquer forma, sempre há uma estreita relação entre a finalidade moral e a tipificação alegorizante do caráter. Assim sendo, trataremos de verificar a construção alegórica do enredo, que se efetiva na relação dramática do protagonista com os demais. Para tanto, perguntamo-nos de que forma pode uma personagem teatral tender à forma alegórica, pergunta que se nos impõe como necessária à análise adequada das personagens da obra em questão. Tentaremos inicialmente delimitar aquilo que se entende por característico da personagem teatral. Em seguida, analisaremos a configuração dramática de Don Juan Tenorio conforme sua relação com as demais personagens de El burlador de Sevilla.

\section{A FÁBULA TEATRAL: ALEGORIA E DIDATISMO}

O preceito dramático do "ensinar deleitando" ganhou ampla difusão em língua espanhola pelas mãos de Alonso López, mais conhecido pelo gentílico "Pinciano", quem publicou, em 1596, a preceptiva Philosofía antigua poética. Remetendo-se à Ars poetica de Horacio, um dos clássicos precursores na defesa do 
caráter edificante do teatro, Pinciano sustenta que os caracteres da tragédia devem "instruir com suas falas honestas e sérias, com suas ações excelsas e honradas". Além disso, defende que cada personagem dever ter o final merecido: "o caráter probo e digno de elogio (...) receberá o prêmio que the cabe, enquanto o malvado será punido." ${ }^{56}$

É sempre possível verificarmos como o teatro foi diversas vezes utilizado com objetivos doutrinários - pensemos como os jesuítas lançaram mão desse recurso na catequese do gentio, exemplo lembrado muito a propósito por Décio de Almeida Prado $^{57}$, ou ainda, nas representações do martírio de Cristo ainda hoje encenadas nas festividades de Páscoa. Ao que tudo indica, a arte teatral possui qualidades ideais para a persuasão de um público determinado. O autor de El burlador de Sevilla, atento a esse fato, parece querer ensinar ao seu espectador, sobretudo, a importância da obra humana perante os olhos de Deus, pois Don Juan Tenorio, embora peça confissão no momento de sua morte, não obtém a salvação da alma devido à sua insistência em pecar, apesar de ter sido várias vezes advertido acerca da justiça divina. E para que a mensagem esteja bem clara, a personagem tem de ser exposta da maneira mais simplificada possível, sem espaço para ambigüidades. Assim, parece haver uma relação estreita entre a finalidade didática e a tipificação do caráter: Don Juan, em última instância, pode ser definido simplesmente pelo seu epíteto de burlador característica que engloba todas as suas falhas de caráter. Desse modo, ele se torna uma figura que tende ao alegórico, no sentido de que, à primeira vista, é a personificação dos valores moralmente condenáveis. Esta tendência ao alegórico, portanto, atende à exigência preliminar do didatismo, tornando-o exemplar. Nesse sentido, o enredo de El burlador de Sevilla aproxima-se da fábula, se definimos esta como uma alegoria em forma de história, e com uma conclusão moral ${ }^{58}$. A "lição de

${ }^{56}$ LÓPEZ PINCIANO. Philosophía antigua poetica. Apud CARLSON, Marvin. Teorias do teatro: estudo histórico-crítico, dos gregos à atualidade. São Paulo: Editora Unesp, 1997, p. 57.

${ }^{57}$ PRADO, Décio de Almeida. A personagem no teatro. In CÂNDIDO, Antonio (org.) A personagem de ficção. São Paulo: Perspectiva, 2004.

58 "A alegoria é comumente distinguida da metáfora por ser mais extensa e detalhada, enquanto a fábula é uma alegoria em forma de história curta e com uma conclusão moral (que pretende ser definitiva). Essa última pertence a um gênero que se supõe hoje inexistente: o didático". KOTHE, Flávio R. $A$ alegoria. São Paulo: Editora Ática, 1986, p.13 
moral" que a fábula transmite é na verdade anterior ao enredo, sendo sua determinante e não sua conseqüência. Segundo Kothe,

A fabulação da fábula é escolhida e montada conforme a necessidade da conclusão. Nesse sentido, a conclusão é anterior à fabulação. A fabulação da fábula existe para levar a essa "conclusão", serve apenas para legitimála. A conclusão é um pressuposto, não uma conclusão. A fábula é uma forma de alegoria, é uma alegoria desenvolvida. Através de elementos concretos procura-se expressar uma idéia 'abstrata'. Que só é abstrata no sentido de escamotear suas raízes sociais e históricas para alcançar maior eficácia apresentando-se como a própria voz da transcendência. ${ }^{59}$

Em alguma medida, El burlador de Sevilla, como boa parte do teatro do Siglo de Oro, realiza uma atualização das antigas moralidades medievais, peças constituídas por longos diálogos entre tipos alegóricos, no sentido mais estrito do termo, de vícios e virtudes. Considera-se o retor Prudêncio o precursor das moralidades por haver sido o primeiro, até onde sabemos, em personificar os conceitos fundamentais da ética cristã em sua obra Psychomachia, um verdadeiro louvor à Cristandade, escrito por volta do ano 400 , onde é retratada uma disputa entre vícios e virtudes pela alma do homem. O gênero, no entanto, apenas se desenvolveu de fato no século $X V$, quando os caracteres alegóricos adquiriram funções diretas na ação. Em território ibérico, as moralidades alcançaram seu melhor momento dentro da obra de Gil Vicente (14701536), a quem se atribui na península a autoria da famosa Todo o Mundo e Ninguém, da qual reproduzimos aqui um trecho bastante exemplar do modo como se estruturavam essa peças:

\section{Ninguém:}

E agora, que buscas lá?

\section{Todo o Mundo:}

Busco honra muito grande.

\section{Ninguém:}

E eu, virtude, que Deus mande

\footnotetext{
${ }^{59}$ Idem, Ibidem.
} 
que tope co ela já.

(Berzebu para Dinato)

Berzebu:

Outra audição nos acude:

escreve aí, a fundo,

que busca honra Todo o Mundo,

e Ninguém busca virtude. ${ }^{60}$

Se se reescrevesse El burlador de Sevilla em forma de moralidade, talvez Don Juan se chamasse "Soberbia" (a Soberba), já que podemos considerar que sua principal falha é a hybris, ao pensar que pode desafiar a tudo e a todos. É evidente que seu caráter, no entanto, apresenta-se de forma mais complexa do que as personificações de representação limitada das moralidades. As personagens de El burlador de Sevilla são como alegorias desenvolvidas, são personagens típicas, sem conflitos internos, dadas as condições históricas e sociais em que se inserem ${ }^{61}$. Vemos que os caracteres das moralidades configuravam-se basicamente por meio das falas, discorrendo sobre os traços de cada vício ou virtude. No entanto, como nos recorda Décio de Almeida Prado, em seu texto supracitado, em linhas gerais, uma personagem teatral configura-se tanto pelas ações, quanto pelo que diz de si mesma (principalmente no recurso do aparte, no qual ela sempre diz a verdade), quanto pelo que as demais personagens dizem a seu respeito. A obra aqui estudada segue essa tendência, afastando-se consideravelmente da configuração dos caracteres das moralidades.

\footnotetext{
${ }^{60}$ VICENTE, Gil. Todo o Mundo e Ninguém. Apud MOISÉS, Massaud. A literatura portuguesa através dos textos. São Paulo: Editora Cultrix, 1999, p.71. Notamos aqui já a noção de honra como boa reputação, um valor extrínseco à pessoa, e não como uma virtude inerente. Cf. pp. 16-17.

${ }^{61}$ Diferentemente do teatro de Shaekspeare, por exemplo, marcado principalmente por conflitos internos das personagens, cujos monólogos encontram-se "já bem mais próximos da marcha real do pensamento, com suas vacilações e incertezas, mas sem perder com isso a sua beleza retórica (...) um dos quais, 'To be or not to be', gravou-se mesmo na imaginação popular como o exemplo mais perfeito da reflexão poética sobre o homem" (PRADO, Décio de Almeida. Op. cit., p. 91). Esses conflitos internos das personagens shaekespearianas tendem a ser a base da unidade de ação das peças, criando a identificação do público com seu aspecto emocional, promovendo, de acordo com Anatol Rosenfeld, o efeito catártico: "A fábula das peças de shaekespearianas desenvolve-se com poderosa necessidade e motivação internas, apesar da freqüente descontinuidade das cenas e da ruptura da ilusão por elementos cômico-burlescos. Esse rigor do desenvolvimento interno corresponde a um teatro ilusionista. Nisso Lessing tem razão, ao considerar Shaekespeare superior aos clássicos franceses na criação de uma atmosfera intensamente emocional e na obtenção do efeito catártico exigido por Aristóteles." ROSENFELD, Anatol. O teatro épico. São Paulo: Perspectiva, 2004, p.73.
} 
Notamos, porém, que a ação, a fala própria e a fala dos demais só formam um todo coerente se nos atentamos à rede de relações de cada personagem. Isto é: a relação que o caráter $A$ estabelece com o caráter $B$ é que determina a ação de A sobre $B$ e o modo como $A$ se apresenta frente a $B$, fatos que por fim determinam o que B opina sobre A. Assim sendo, nunca podemos analisar a personagem teatral isoladamente, e sim inserida nas relações com os outros e na totalidade da obra dramática. Como muito bem nos ensina o crítico Francisco Ruiz Ramón:

Para interpretar, pues, el sentido de un personaje o de una escena no hay que aislar a aquél o a ésta de los otros personajes o de los otros momentos, ni ambos - personaje y situaciones - del universo en que están integrados (...) Todo personaje es así, desde un punto de vista estructural, una reciprocidad de personajes, como cada escena una reciprocidad de escenas. El análisis crítico de la estructura dramática exige, en consecuencia, ir de lo estructurado a lo estructurante. ${ }^{62}$

Analisemos, então, como se relaciona Don Juan com as demais personagens e como ele se insere na macroestrutura dramática de El burlador de Sevilla.

\section{FORMAÇÃO DE DON JUAN POR ANTÍTESE}

Décio de Almeida Prado afirma que, dentre os três modos de caracterização da personagem - através de suas ações, do que diz de si mesmo e do que dizem os outros a seu respeito - , o mais eficaz é aquele que nos transmite sua natureza através das ações. Em suas palavras: "Drama, em grego, significa etimologicamente ação: se quisermos delinear dramaticamente a personagem devemos

${ }^{62}$ RUIZ RAMÓN, Francisco. Estudios de teatro español clásico y contemporáneo. Madrid: Fundación Juan March/Cátedra, 1978, p. 26. 
ater-nos, pois, à esfera do comportamento, à psicologia extrospectiva e não introspectiva. ${ }^{163}$ Assim, somente através das atitudes é que se constrói a história e a narração desta é sempre o principal objetivo do teatro. Neste ponto, o crítico se coloca em consonância com Aristóteles, que defendeu a supremacia do enredo (também chamado de mito) sobre os demais elementos integrantes da obra teatral, distinguindoos da seguinte maneira:

Ora, o mito é imitação de ações; e por 'mito', entendo a composição dos atos; por 'caráter' o que nos faz dizer das personagens que elas têm tal ou tal qualidade; e por 'pensamento, tudo quanto digam as personagens para demonstrar o que quer que seja ou para manifestar sua decisão. ${ }^{64}$

Segundo o filósofo grego, seria possível, por exemplo, haver tragédia sem caracteres, mas não poderia havê-la sem ação, pois por melhores que sejam as elocuções e os pensamentos, nem por isso estes lograrão algum efeito sobre a platéia, ao passo que a tragédia que utilizá-los com parcimônia, e enfatizar o mito/enredo, certamente o conseguirá. Notamos, porém, que evidentemente, em momentos distintos da história do teatro existiram formas que não privilegiavam o enredo sobre os caracteres, sendo o mito/enredo a conseqüência da índole das personagens ${ }^{65}$. No entanto, é claro que, devido aos fatores históricos do período em que se insere El burlador de Sevilla, encontramo-nos com uma peça que privilegia o enredo e não os caracteres, fato decorrente de seu objetivo moralizador, já que é o enredo que efetua a transmissão da mensagem edificante, sendo a personagem uma espécie de intermediário entre esta, manifestada no enredo, e o público, que será seu receptor.

${ }^{63}$ PRADO, Décio de Almeida. Op. cit., p.91.

${ }^{64}$ ARISTÓTELES. Arte retórica e arte poética. São Paulo: Difusão Europeia do Livro, 1964. Trad. Antonio Pinto de Carvalho. Aristóteles dividia a tragédia em mito, caráter, pensamento, elocução, espetáculo e melopéia. Destacamos os três primeiros elementos por serem os mais pertinentes à análise aqui empreendida.

${ }^{65}$ Segundo Rosenfeld, é sempre possível perceber no teatro ou uma tendência a enfatizar a ação ou uma tendência a enfatizar a índole das personagens. Ao citar o teatro de lbsen, por exemplo, classifica-o como "drama analítico", em que "a ação nada é senão a própria análise dos personagens e da situação." ROSENFELD, Anatol. Op. cit. p. 85-90 passim. 
Assim sendo, o enredo de El burlador de Sevilla é facilmente resumível e compreensível.

A repetição de ações enganosas por parte de Don Juan culmina com o assassínio de Don Gonzalo. É esse o conflito que deverá ser solucionado até o final da peça. Até esse momento, o que se assiste é a ilustração de dois tipos antagônicos: o jovem arrogante e o velho sábio, caracteres que se delineiam principalmente por suas atitudes opostas frente à autoridade do rei - a qual Don Juan ofende tanto quanto Don Gonzalo a engrandece -, e também pelas posturas frente à devoção cristã, presente de forma inconteste no comendador e referida com escárnio por Don Juan.

Don Juan monta sua armadilhas com o objetivo de seduzir mulheres. Mas a sedução do ponto de vista de Don Juan não é uma conquista amorosa, uma estratégia daquele que busca arrefecer a resistência da pessoa desejada, como a pensamos de forma mais corrente nos nossos dias. A sedução para ele é uma forma de humilhação através do engano, e cada vítima, uma espécie de degrau em sua escalada rumo àquela fama que ninguém mais pode alcançar.

Nota-se, no entanto, que Don Juan Tenorio não é exatamente a figura de irresistível conquistador e performático sexual em que se transformaria em versões posteriores. Como bem nos recorda Mario M. González

\begin{abstract}
En el itinerario de Don Juan que va de la alcoba de Isabela a la tumba de Don Gonzalo, sin embargo, la seducción como tal ocupa un espacio bastante limitado. Ante las dos mujeres nobles, Isabela y Doña Ana, Don Juan procede a las más burda substitución de persona. No es él, así, quien ha seducido, sino que él aprovecha la oscuridad para hacerse pasar por los seductores de ambas. Ante las dos mujeres villanas, la pescadora Tisbea y la campesina Aminta, Don Juan hace valer, ante todo, su rango social y la riqueza que éste conlleva. ${ }^{66}$
\end{abstract}

Isso equivale a dizer que, para conseguir uma mulher, Don Juan simplesmente "dá" a esta o que ela quer, fingindo propiciar aquilo que ele sabe que é ${ }^{66}$ GONZÁLEZ, Mario Miguel. Don Juan: burlador, seducido y seductor. In ABREU VIERA DE OLIVEIRA, Ester e MIRTIS CASER, Maria (Orgs.). Universo Hispánico - Lengua, Literatura, Cultura. Vitória: UFES/APEES, 2001, pp. 212-214. 
desejado. Para Isabela e Ana, ele "realiza" o desejo de estarem com seus amados; para Tisbea e Aminta, Ihes "dá" a "oportunidade" de casamento com um nobre. Nesse sentido, atua como um demônio, que só pode agir através do ponto fraco de uma pessoa. Afinal, essas mulheres não agiram mal porque foram induzidas por Don Juan, e sim porque sucumbiram a uma vontade inadequada aos preceitos sociais e religiosos.

Nesse sentido, é interessante analisarmos a concepção de controle das paixões que está em cena - controle que tais mulheres não conseguem exercer. Trata-se de conceber o controle das vontades não como o governo racional de si mesmo - como o seria para os antigos, baseados na ética aristotélica -, e sim como um requisito para a salvação da alma - parâmetro tipicamente católico. Se para os gregos o desejo não era considerado indigno em si, somente se fosse dirigido a objetos indignos - pois o homem virtuoso deseja o adequado - , o catolicismo rechaça a priori sua existência, numa espécie de neoestoicismo em que a anulação do desejo possui um valor de ascensão espiritual. Sucumbir a uma fraqueza, a um pecado, equivale a um empecilho à salvação cristã:

\begin{abstract}
El cristianismo (...) postulará el renunciamiento a sí mismo como una condición para hallar la verdad; pues ésta no reside en el sujeto, sino en la sujeción a la ley. De este modo, la práctica de la 'obediencia' es lo que le permite al sujeto encontrar la verdad y acceder a su salvación (...) Esta supremacía de lo eclesiástico y la subordinación del sí mismo a una norma única y totalizante, será pues lo que establecerá las condiciones del 'poder pastoral'. Así, de la ascesis antigua, a la ascesis cristiana, se pasa de una matriz de subjetivación a una subordinación o sumisión del sujeto a la ley divina. ${ }^{67}$
\end{abstract}

Em El burlador de Sevilla, a voz histórica e social que quer se apresentar como transcendente é, evidentemente, a voz da Igreja e do Estado, que compunham na Espanha um uníssono. Notamos que essa voz encarna na figura de Don Gonzalo de Ulloa, que, como sabemos, tanto é um dos privados do rei de Castilla, quanto representante da ordem religiosa de Calatrava. Nesse sentido, o comendador é uma

\footnotetext{
${ }^{67}$ NAUGHTON, Virginia. Historia del deseo en la época medieval. Buenos Aires: Quadrata, 2005, pp.6465.
} 
personagem que sintetiza os valores positivos que se devem apreender da representação da obra. Don Gonzalo, assassinado por Don Juan quando pretendia defender a honra de sua filha, é a representação legítima do Pai, Senhor, Deus. Luta para preservar justamente aquilo que o burlador quer tirar das mulheres, tomando para si. O combate entre duas forças diametralmente opostas resulta, é claro, na vitória do lado que encarna não apenas uma manutenção do sistema social - pois Don Juan também defende a preservação dessa estrutura que, como já vimos, o protege -, mas que representa uma espécie de saneamento moral, de correção exemplar de conduta.

Don Juan, por sua vez, afirma que "burlar uma mulher e deixá-la sem honra" é seu maior prazer. Nesta afirmação certamente se explicita a intenção pedagógica do autor, mostrando que há homens "desse tipo" soltos por aí e que, portanto, as donzelas deveriam se resguardar. Tomar a honra, que era um valor fundamental para aquela sociedade, demonstra que Don Juan desempenha uma função social, pois reforça a idéia de que é necessário preservar a mulher a todo custo, já que é depositária da honra dos homens. Ou seja: configurando-se como um representante dos valores condenáveis dentro daquela estrutura, sua atuação visa ao fortalecimento de seus valores ideais. Assim, a principal função de Don Juan dentro da obra é a de reforçar, por antítese ao comendador, os valores em funcionamento naquele universo. Embora a história seja narrada como ocorrida no século XIV, é evidente que o que se quer ilustrar são os males da sociedade contemporânea aos espectadores $^{68}$, e assim sendo, Don Juan Tenorio empreenderá sua missão às

\footnotetext{
${ }^{68}$ Ao projetar a história em um passado distante, nos parece que o autor tenta evitar a possível identificação de personalidades e autoridades contemporâneas que poderiam ser facilmente relacionadas com personagens que no enredo estavam ligadas ao rei. Além disso, o autor também realiza um afastamento espacial, como nos mostra o crítico John Varey: "La Sevilla corrupta es la ciudad de Sevilla, y no la Corte real, la que no es atacada. El menosprecio de corte de los moralistas del siglo XVI claramente influyó a Tirso en su ataque contra la vida corrupta de la ciudad. Pero la palabra 'corte' tenía dos acepciones en la España del siglo XVII: podía referirse a la ciudad o al palacio, esto es al séquito de cortesanos y ministros que acompañaban al Rey. Pero aunque la Corte del Rey español sale más 0 menos ilesa - a pesar del ataque contra la ciudad de de Sevilla - , no por eso deja la inmoralidad de una Corte - la del Rey de Nápoles - de ser atacada sin clemencia en la obra. Sin duda por razones políticas, Tirso decidió que sería más sensato atacar la Corte napolitana que la de Alfonso XI de Castilla. El moralista muestra prudencia, y no sin razón, al seleccionar su blanco.” In VAREY, J. Op. cit. p.139.
} 
avessas, defendendo, por oposição, o saneamento do sistema social atuante na Espanha do XVII. Esse reforço por contraste se dá em diversos níveis:

a) sendo um enganador de mulheres, mostra a importância da "honra feminina", nesse contexto reduzida à mera aparência, opinião do grupo sobre determinada mulher, que é portadora da honra dos homens que têm relação direta com ela: o pai, o irmão, o marido, o filho;

b) sendo alguém que afirma constantemente "ter tempo de sobra" frente às advertências que recebe ao longo da peça para se arrepender, revela a necessidade de se observar sempre a obra humana para se tornar merecedor da misericórdia divina;

c) sendo alguém que quer se destacar e alcançar uma fama cuja natureza não é a de aproximá-lo mais à autoridade real - como certamente seria o desejo daquela nobreza, ávida de proteção e regalias inerentes a essa proximidade - mas que o faz "pairar" por toda uma sociedade que se pensa como corpo místico, reforça a importância de que sejam sempre obedecidas as regras e as leis que mantêm cada parte desse corpo hierárquico em seu devido lugar.

A presença de Don Juan como um desafio à estabilidade desse sistema serve, portanto, para contornar melhor o que seja essa sociedade, cujos valores modelares encarnam na figura do Convidado de pedra. A função do antagonista é, assim, precisar o contorno do herói; e ambos, finalmente contornados e definidos alegoricamente, desempenham com grande eficácia o papel que Ihes fora destinado: o de educar, através do exemplo, a sociedade espanhola de seu tempo. 


\section{SIGNOS CONVENCIONAIS EM EL BURLADOR DE SEVILLA}

Ainda sob essa perspectiva do didatismo, percebemos a presença de signos convencionais na obra, isto é, de significantes que evocam significados já consolidados culturalmente. Ao manipular esses "conhecimentos prévios" do público, a obra pode reforçar ou pôr em xeque o ensinamento contido no significado préestabelecido. Neste trabalho, analisaremos três das convenções que se articulam em El burlador de Sevilla: o romance que forneceu o tema do jovem que afronta o além; o tema da aldeia como espaço da honra e da corte como espaço do vício; e a tópica folclórica do "burlador burlado".

\section{ORIGEM FOLCLÓRICA}

O fundo social presente em El burlador de Sevilla foi acrescentado a um romance popular bastante difundido na época, e que apresentava a configuração básica do tema desenvolvido na peça, como veremos. O romanceiro popular ibérico foi fonte de versos variáveis sobre a história de um jovem que ofende a figura de um defunto. Dentre as variantes folclóricas recolhidas por Said Armesto, transcrevemos uma que nos parece suficientemente exemplar da presença do tema no folclore ibérico, e que contém muitos aspectos que também se apresentam na fabulação de El burlador de Sevilla:

Camiñaba Don Galán / para misa de Cuaresma, non por devoción da misa / nin por otra que tuviera, iba por mirar las damas / que salían de la iglesia. Na porta do camposanto / encontró una calavera que seus dentes lle griñaba / como si de él se riera. Don Galán cand'a mirou / una patada le diera:

- Calavera, eu te convido / esta noche a miña cena.

A cosa de media noche / cantan los gallos afuera.

A cosa de media noche / Don Galán pide la cena.

Aun bocado non probara / cuando petan a la puerta. 
- Da palabra que me deches, / Don Galán, non te m'esquenzas

- Non m'esquenzo da palabra / nunca de ela m'esquencera:

Ahí tes preparada silla / prato, cuberto e cullera.

Sentárase muy a modo / a cenar la calavera,

de ricos pratos que había / de todos ellos comiera.

- Come, come, el convidado, / que la sopita está buena.

Estando ' $n$ estas razones / la calavera dijera:

- Vente, Don Galán, conmigo / esta noche a miña cena, ven conmigo al Camposanto / que mellor cousa te dera.

Ao redor do Camposanto / se prepara una gran festa, encendidos na capilla / moitos cirios e candelas, no medio d'aquelo todo / una sepultura aberta.

- Entra 'n esta sepultura / a comer da miña cena.

- Eu aquí non entro, non / que esa mmira non truxera.

- Que a trayas, que non a trayas, / entrarás, vilano, 'n ella, ca luz tua acá s'acaba / y o teu corpo morto queda. ${ }^{69}$

Até mesmo o nome do jovem, Don Galán, parece ecoar no nome de Don Juan, por assonância. Podemos comprovar que este último também é considerado um galante pelas demais personagens:

\section{Gaseno: \\ ¿Quién viene?}

\section{Catalinón:}

Don Juan Tenorio

\section{Gaseno:}

¿El viejo?

\section{Catalinón:}

No ese Don Juan

\section{Belisa:}

Será su hijo galán.

\footnotetext{
${ }^{69}$ Recitado por Rita Beleiro, 61 años, lavradora residente en Cuñas, província de Orense, Espanha, em julho de 1903. In SAID ARMESTO, Victor. La leyenda de Don Juan. Buenos Aires: Espasa-Calpe Argentina, 1946, pp. 29-30.
} 


\section{Batricio:}

Téngolo por mal agüero, que galán y caballero quitan gusto y celos dan. ${ }^{70}$

\section{E também:}

\section{Fabio:}

Que si a Octavio perdiste más galán es Don Juan, y de notorio solar. ${ }^{71}$

Há no romance popular o desrespeito de um "Don Galán" com uma caveira à porta do cemitério. Antes disso, porém, já estava sendo cometido um outro deslize, já que desrespeitava a própria missa, ao flertar com as moças ali presentes. Esse traço mulherengo será uma das bases de Don Juan Tenorio. O desrespeito com o além encontra-se agravado em El burlador de Sevilla pelo fato de que Don Juan não só desrespeita um morto, como o faz Don Galán, mas desrespeita um homem que havia assassinado, e que era um modelo de conduta religiosa, política e paterna. Assim sendo, Don Juan não só afronta o além, mas toda a ordem histórica que Don Gonzalo de Ulloa encarna; Don Gonzalo é tanto uma representação da Igreja quanto o é do Estado, basta recordar-nos da descrição elogiosa que faz dos conventos lisboetas ao rei espanhol, demonstrando um orgulho que tanto é devocional quanto patriótico ${ }^{72}$. Ou seja, ao elaborar a obra sobre um tema folclórico, acrescentou-se um fundo histórico que determina sua moral, mas que quer apresentar-se como a verdade, como uma voz atemporal, transcendente. Sabemos, no entanto, que essa "verdade" é uma mera convenção, e que o enredo não busca nada mais do que reforçar uma estrutura social. O público de El burlador de Sevilla não estava aprendendo nada novo sobre pecado e castigo, apenas estava sendo "lembrado" de suas obrigações. Precisamente por isso a

\footnotetext{
${ }^{70}$ Versos $1732-1737$

${ }^{71}$ Versos 2165-2166

${ }^{72}$ Versos 743-784.
} 
alegoria em cena é de facílima compreensão, apresentando signos convencionais naquele universo, inclusive ao evocar a lenda do jovem galante que ofende os mortos.

\section{A HONRA ALDEÃ E O VÍCIO CORTESÃO}

Mas não somente a evocação do romance popular é um recurso convencional dentro da peça - convencional no sentido de evocar uma correspondência já consolidada socialmente entre significante e significado, simplesmente reafirmando essa relação. O convencionalismo é um princípio eficiente de apelo popular em El burlador de Sevilla, pois o uso de signos já assentados culturalmente facilita o (re)aprendizado dos preceitos morais em cena. O público contemporâneo à peça, ao assistir o convite de Don Juan à estátua de pedra de Don Gonzalo, certamente se recordaria do enredo do romance, cuja evocação reforça, basicamente, o respeito que se deve guardar aos mortos. Além dessa alusão, como veremos, toda a obra está pautada por signos consagrados do universo social retratado.

Uma outra convenção, muito difundida na Espanha do XVI e XVII, é a tópica que considera o campo como espaço de virtudes e a corte como espaço de vícios, cujo eco encontramos na boca do próprio Don Juan, que ironiza o modo como o aldeão Batricio abre mão de sua esposa por uma "questão de honra":

\section{Don Juan:}

Con el honor le vencí, porque siempre los villanos tienen su honor en las manos y siempre miran por sí, que por tantas variedades es bien que se entienda y crea 
A origem dessa associação remonta à necessidade de se provar a "limpeza do sangue de cristão velho", já que a vida nas aldeias praticamente impedia o anonimato que poderia ocultar um cristão novo (judeu converso), ao contrário do ambiente urbano e cortesão. Dentro de El burlador de Sevilla, vemos essa associação na fala de Gaseno, que ao tentar ajudar Arminta a reclamar o casamento com Don Juan, empenha-se em demonstrar a Octavio que, por ser uma "cristã velha", sua filha é suficientemente digna de casar-se com um nobre:

\section{Gaseno:}

Doña Arminta es muy honrada cuando se casen los dos, que cristiana vieja es hasta los huesos, y tiene de la hacienda el interés, y a su virtud aún le aviene, más bien que un Conde, un Marqués. ${ }^{74}$

A visão do campo como espaço da virtude, no entanto, sobreviveu ainda quando não necessariamente aludisse à religião. Além disso, também é recorrente a idéia de que do poder de um cavalheiro sempre advém algum mal, como vemos na fala de Batricio: "Bien dije que es mal agüero / en bodas un poderoso". ${ }^{75}$

Esse lugar-comum de associação da virtude com o campo e do vício com a corte foi tema abordado e desenvolvido por Antonio de Guevara, que diferenciava camponeses de cortesãos em variados aspectos, dentre os quais o valor que cada um dá à honra:

Es privilegio del aldea que allí sea el bueno honrado por bueno y el ruin conoscido por ruin, lo cual no es así en la corte ni en las grandes repúblicas,

\footnotetext{
${ }^{73}$ Versos 1932-1939

${ }^{74}$ Versos 2684-2692.

${ }^{75}$ Versos $1798-1799$
} 
a do ninguno es servido y acatado por lo que vale sino por lo que tiene (...) Es privilegio de aldea que allí sean los hombres más virtuosos y menos viciosos, lo cual no es así por cierto en la corte y en las grandes repúblicas, a do hay mil que os estorben el bien y cien mil que os incite al mal. ${ }^{76}$

Em El burlador de Sevilla, no entanto, a tão louvada pureza do espírito camponês parece manifestar-se integralmente apenas na personagem de Batricio, que se mostra bastante confuso frente ao comportamento "cortesão" de Don Juan Tenorio:

\section{Batricio}

Pues cada vez que quería metella, la desviaba, diciendo a cuanto tomaba: "Grosería, grosería".

\section{(...)}

Pues llegándome a quejar a algunos, me respondían, y con su risa me decían: "No tenéis de qué os quejar; eso no es cosa que importe; no tenéis de qué temer. Callad, que debe de ser uso de allá de la Corte." Buen uso, trato extremado. Más no se usara en Sodoma: que otro con la novia coma, y que ayune el desposado. ${ }^{77}$

Arminta, que acaba cedendo sem muito esforço ao "casamento" com Don Juan, também desconfia, antes de entregar-se, de seu cavalheirismo:

\section{Arminta:}

$\mathrm{Di}$, ¿qué caballero es este que de mi esposo me priva? La desvergüenza en España

\footnotetext{
${ }^{76}$ GUEVARA, Antonio. Menosprecio de corte y alabanza de aldea. Edición de Asunción Rallo Gruss. Madrid: Cátedra. p.177, 179.

${ }^{77}$ Versos $1844-1847$ e 1856-1867.
} 
se ha hecho caballería. ${ }^{78}$

Além de Arminta, outros camponeses parecem desviar-se do modelo de virtude que o lugar-comum Ihes impunha: podemos percebê-lo em Belisa, que tão entusiasmada se mostra com a chegada de Don Juan, e no comportamento totalmente deslumbrado de Gaseno, no momento em que recebe aquele no casamento de sua filha:

\section{Gaseno:}

Venga tan gran caballero a ser hoy en Dos Hermanas

honra de estas nobles canas. ${ }^{79}$

E quando a entrega ao sedutor:

\section{Gaseno:}

Acompañaros querría por darle de esta ventura el parabién a mi hija

\section{Don Juan:}

Tiempo mañana nos queda

\section{Gaseno:}

Bien decís. El alma mía en ella os ofrezco. ${ }^{80}$

Excetuando-se Batricio, vemos que a inocência aldeã encontra-se corrompida, fascinada com a riqueza e o poder da corte, que penetra nesse universo

\footnotetext{
${ }^{78}$ Versos $1960-1963$

${ }^{79}$ Versos 1758-1760

${ }^{80}$ Versos: $1977-1982$
} 
através de Don Juan Tenorio. No pólo oposto, Don Gonzalo e Don Juan, o velho, constituem uma exceção à corrupção e má-fé que se alastram em ambiente cortesão. Assim, trabalhando sobre o convencionalismo que associa a virtude ao campo e o vício à cidade, o autor mostra que essa relação não é forçosamente verdadeira: corrupção e valor podem ser encontrados em qualquer parte, já que há aldeães viciosos e cortesãos virtuosíssimos. Desse modo, reafirma-se em outro nível que o homem não é um ser sobredeterminado, nem mesmo pelo meio em que vive, pois detém o livre-arbítrio para escolher seu caminho.

\section{TÓPICA DO BURLADOR BURLADO}

O único desejo de Don Juan é enganar a todos ao seu redor. Esse aspecto aproxima-o do tipo folclórico conhecido como trickster - "aquele que faz truques" - , e que na literatura clássica é bem representado por Ulisses, o idealizador do cavalo de Tróia. O trickster sempre foi um motivo recorrente em diversas mitologias ao redor do mundo, transmitindo aos povos a noção de que todos são vítimas potenciais do engano, inclusive o enganador-mor. López-Vázquez ${ }^{81}$ já havia advertido que a personagem em muitos aspectos assemelha-se a essa figura, o enganador sem freios que um dia, finalmente, é enganado. Notamos essa aproximação, por exemplo, em um comportamento recorrente de Don Juan: ele alterna momentos de supressão do eu - quando se esconde, passando por outras pessoas, ou quando pede a Catalinón que não revele à seduzida quem ele é - com momentos em que se torna um "superindivíduo", ao querer elevar-se muito acima de todos os homens - nos momentos posteriores às conquistas, quando ele almeja a fama de seu nome ("Ha de ser burla de

${ }^{81}$ RODRÍGUEZ LÓPEZ-VÁZQUEZ. Introducción. In MOLINA, Tirso de (atribuida a). El burlador de Sevilla. Madrid: Cátedra, 1990, p. 27. O autor também nota que Tisbea funciona como um contraponto feminino, de "burladora burlada": "Tisbea participa en la burla al ocultarle a Don Juan el hecho de que conoce su identidad. Dramáticamente el fondo de ese episodio está prefigurando ya el esquema de construcción del mito: quien burla primero, más tarde será burlado" Idem, p. 57. 
fama", em suas palavras). Nesse sentido, ele é um verdadeiro trickster, que usa de qualquer artimanha para efetuar seus engodos ${ }^{82}$.

Também é possível verificar a existência de embusteiros anteriores no histórico do teatro espanhol dos séculos XVI e XVII, que parecem oferecer alguns episódios básicos de El burlador de Sevilla. Uma delas chama-se El infamador, de Juan de la Cueva, representada em Sevilha em 1581. Nela aparece um homem dissoluto, Leucino, cujo foco é a calúnia contra uma única vítima, e que receberá mais tarde um castigo sobrenatural. Há também uma peça de Lope de Vega, datável entre 1595 e 1603, chamada La fuerza lastimosa, que apresenta um duque Octavio que, nas cenas iniciais, escuta a filha do rei marcar um encontro com um conde, e aproveita para enganá-la, passando-se por este. La serrana de la Vera, também de Lope, datável entre 1595 e 1598 apresenta uma "burladora burlada", que talvez tenha algo de modelar para a pescadora Tisbea. Desse modo, percebe-se o manejo, em El burlador de Sevilla, de alguns pontos já trabalhados com êxito em peças antecedentes, além da manipulação evidente do tipo popular do embusteiro.

Segundo o estudioso Marc Vitse, no entanto, o itinerário de Don Juan Tenorio conduz a uma mudança na acepção do verbo "burlar", pois se em princípio ele aparece com o significado de "enganar, ludibriar", evolui para um sentido de "rir-se de, mofar-se"; assim sendo, a índole da personagem passa da burla-engano à burlazombaria $^{83}$. Também podemos interpretar essa evolução como a confirmação de uma ultrapassagem que se efetua do nível do trickster para o nível daquele que comete hybris, isto é, uma progressão do enganador-mor para o orgulhoso desmedido que ridiculariza a todos, pois os tem como seres inferiores, presas fáceis e dignas de gozação. Don Juan é um ser excessivo, não tem prudência - prudência no sentido de justa medida, em oposição à hybris —, e essa sua desmedida o torna cômico. O caráter cômico aqui é exclusivamente entendido como participando daquela instância que dá

${ }^{82}$ Quanto ao fato de lançar mão de qualquer recurso para atingir sua finalidade, já foi dito por Gregorio Marañón que Don Juan seria o exemplo de um certo maquiavelismo aplicado à prática amorosa. MARAÑÓN, Gregorio. Don Juan e o donjuanismo. Apud RIBEIRO. Op. cit. p. 15.

${ }_{83}$ VITSE, Marc. Las burlas de Don Juan: viejos mitos y mito nuevo. In RUIZ RAMÓN, F. y OLIVA, C. (coord.). El mito en el teatro clásico español. Madrid: Taurus, 1988, p.182 
conta do feio, que pode ser inocente, causando o riso, ou vicioso, causando o horror caso em que obviamente se insere o burlador.

É notável, no entanto, o fato de que Don Juan não é o único culpado dentro da peça, mas é o único que é castigado. O crítico Francisco Ruiz Ramón já advertiu quanto a esse aspecto de El burlador de Sevilla, concluindo que o encerramento da ação é conflitivo, não efetuando a restauração da ordem, como seria de se esperar:

\begin{abstract}
Que sólo Don Juan reciba castigo, y tan tremendo, pero no los otros - ni siquiera un castigo menor apropiado a sus culpas - , debe hacernos meditar en por qué no se cumple el principio de la justicia poética, sino antes bien el de la injusticia poética, en esos otros personajes. No me parece que sea en este drama - como en otros - lo significativo el principio de la justicia poética, sino su valor relativo y, especialmente, la contradicción patente entre justicia y no-justicia poéticas. ${ }^{84}$
\end{abstract}

O autor define essa situação como um caso em que a justiça poética não contém necessariamente uma justiça moral: o que acontece no final da peça é apenas uma ordem aparente, que não consegue, porém, sanar todos os setores corrompidos, dos quais Don Juan se aproveitava para enganar e conquistar a fama de seu nome. Como já foi dito, ele só pode enganar porque há brechas que lhe permitem, e essas brechas são, exatamente, as falhas das suas vítimas, que também pecam, ainda que seja de forma aparentemente "menos grave".

Assim sendo, notamos que a presença de Don Juan como embusteiro-mor funciona como uma denúncia dos pequenos pecados cometidos por quase todos os retratados, pois são esses que permitem a atuação de um mal maior, demoníaco, o qual ele encarna. Mais uma vez, percebe-se sua identificação com o diabólico, pois assim como o demônio, Don Juan não obriga ninguém a pecar, apenas aproveita-se daqueles que já estavam predispostos, por assim dizer.

\footnotetext{
${ }^{84}$ RUIZ RAMÓN, 1988, p. 36.
} 


\section{CAPÍTULO 3}

\section{O CONFRONTO ENTRE DOIS ABSOLUTOS}

Como vimos no capítulo anterior, Don Juan é uma personagem que traz em sua composição traços do trickster. Neste capítulo, analisaremos o modo pelo qual a personagem ultrapassa esse tipo folclórico, identificando-se com qualidades somente atribuíveis a personagens míticas. Trataremos de verificar como a peça El burlador de Sevilla evoca elementos míticos em sua trama e nos caracteres de Don Juan Tenorio e Don Gonzalo de Ulloa, personagens que se submetem a um mito cuja finalidade é a defesa de uma ordem social.

\section{SER E NÃO SER - EIS DON JUAN}

A hipótese de Don Juan confirgurar-se como mito parece ser confirmada por sua relação com a existência temporal: simultaneamente Don Juan se afirma como ser que existe em seu refrão: "soy un hombre..." e se nega como indivíduo, "...sin nombre". Como a negação do nome anula a primeira informação, a de "ser um homem" (já que o nome, de certa forma, é condição inerente a todo homem), a única mensagem que realmente se processa é a de que Don Juan é. Ele afirma apenas sua existência imediata e presente, ignorando o passado (que seria dado por sua origem, o seu nome) e o futuro (no seu refrão complementar " $i Q u e ́$ largo me lo fiáis!"). Cremos que essa é a absoluta afirmação de um presente contínuo, o tempo dos mitos. Ele estaria portanto mais próximo ao ciclo mítico em contraposição à fixidez do convidado de pedra que é quem dá um final (a idéia de um término, de um tempo retilíneo) à repetição de burlas (uma repetição que tende ao infinito, um tempo cíclico). O erro de Don Juan parece ter 
sido justamente acreditar numa suposta equivalência de status entre ele e a estátua do comendador (cometendo o pecado da hybris), pois esta representa o peso da eternidade, enquanto o burlador, conforme apontado por González, apresenta uma atemporalidade que está diametralmente oposta à noção do eterno, pois trata-se de um instante absoluto.

\begin{abstract}
A capacidade de Don Juan para o engano é a manifestação básica de sua superioridade, o que faz com que ele seja inatingível para a justiça humana que, exercida pela mesma classe social à qual pertence, jamais consegue atingi-lo. Essa superioridade se apóia no fato de que Don Juan desconhece o tempo, isto é, seus atos carecem da perspectiva temporal. Assim, ele jamais se preocupa com o futuro, como prova sua resposta - "icuán largo me lo fiáis!" - às reiteradas advertências de que à hora da morte pagará pelos seus crimes. Não há projetos, a não ser imediatíssimos: possuir essa mesma noite a mulher que acaba de conhecer e fugir logo mais. Do mesmo modo, não existe o passado para Don Juan: ele jamais reflete sobre seus atos, o que elimina por completo que possa carregar a noção de culpa (...) Sua vida tem, para ele, um sentido de eternidade, pois vê a existência como uma interminável sucessão de instantes independentes. Em última instância, Don Juan é isso: a encarnação de um absoluto atemporal que, na falta de outra designação melhor, chamamos de "instante". ${ }^{85}$
\end{abstract}

Laymert Garcia dos Santos também faz notar a relação existente entre tempo e vontade para Don Juan:

\begin{abstract}
O homem se crê senhor do tempo. E alegremente se convence de que pode tudo; antes de mais nada: satisfazer todos os seus imperiosos desejos. E se tudo pode, é porque, senhor do tempo, estaria acima de qualquer lei - seu limite é a duração e a intensidade de sua vontade, da força de sua vontade. ${ }^{86}$
\end{abstract}

Quanto ao fato de se afirmar sob um aspecto e se negar sob outro também pode ser interpretado como a negação do papel institucional / social: ele se afirma como "animal / instinto" ("soy un hombre") e se nega como ser em sociedade / aculturado ("sin nombre"). De qualquer forma a sua força mítica está sempre preservada ao se distinguir e se elevar das premissas do que é "ser humano" segundo

${ }^{85}$ GONZÁLEZ, Mario Miguel. Introdução. In MOLINA, Tirso de (atribuída). O burlador de Sevilha e o convidado de pedra. Trad. Alex Cojorian. Brasília: Círculo de Brasília, 2004, p.26.

${ }^{86}$ SANTOS, Laymert Garcia dos. Don Juan e o nome da sedução. In RIBEIRO. Op. cit. p. 24. 
a sociedade que o cerca: todo homem deve ter um nome, deve ter limites, deve temer a justiça de Deus e dos homens, deve ter a consciência de sua finitude, deve amar e respeitar o próximo, etc. Don Juan, simplesmente quebra todas as expectativas do mundo ao seu redor. Essa singularidade, de fazer o que nenhum outro homem é capaz, Ihe confere o caráter de trickster - no sentido de ser alguém mais esperto que os demais, e valer-se disso. No entanto, o retorno da estátua do comendador do alémtúmulo, como única instância capaz de puni-lo, confirma que Don Juan não é somente mais um "burlador burlado", e sim a encarnação do Mal, tornando-se um "burlador absoluto", que é punido pelo Bem supremo. É o momento final de enfrentamento entre o Bem encarnado em Don Gonzalo e o Mal encarnado em Don Juan que ressignifica o enredo de El burlador de Sevilla, pois é quando evidencia-se seu aspecto mítico, de confronto entre absolutos.

\section{FUNÇÕES DO MITO}

Os mitos muitas vezes são utilizados em forma de alegorias da ciência, da religião ou da moralidade, explicando ou ilustrando uma lei, um argumento ou uma situação, como bem nos mostra Northrop Frye, e, assim sendo, podem ser interpretados alegórica ou dogmaticamente ${ }^{87}$. O mito religioso em cena em El burlador de Sevilla visa, basicamente, a ilustração do refrão "No hay plazo que no llegue, ni deuda que no se pague", tantas vezes proferido ao longo da peça.

Do ponto de vista sociológico, o mito sempre tem uma função que ultrapassa o mero entretenimento. Segundo o antropólogo norte-americano Joseph Campbell, o mito pode assumir quatro funções distintas, segundo sua finalidade: mística, cosmológica, pedagógica e sociológica. A função mística prevalece nos mitos que dão conta do mistério transcendente do universo, do enigma da vida em todas as

\footnotetext{
${ }^{87}$ FRYE, N. Fábulas de Identidade. São Paulo: Nova Alexandria, 2000, p. 40
} 
suas formas. A segunda função, a cosmológica, relaciona-se com o papel que atualmente é considerado como campo exclusivo da ciência, "mostrando qual é a forma do universo, mas fazendo-o de uma tal maneira que o mistério, outra vez, se manifesta"88. Já os mitos cuja intenção é pedagógica devem ensinar aos homens o modo como viver em qualquer circunstância, independentemente da sociedade em que se encontrem - portanto dizem respeito à natureza humana universal. Na função sociológica, à qual nos interessa chegar, o que importa realmente é a validação de uma ordem social. Nessa categoria, tem-se a defesa dos princípios éticos de determinada comunidade através da ilustração que o mito proporciona. Esses mitos "variam tremendamente, de lugar para lugar. Você tem toda uma mitologia da poligamia, toda uma mitologia da monogamia. Ambas são satisfatórias. Depende de onde você estiver"89. Embora a história seja narrada como ocorrida no século XIV, é evidente que o que se quer ilustrar são os males da sociedade contemporânea aos espectadores, e assim sendo, Don Juan Tenorio empreenderá sua missão às avessas, defendendo por oposição a manutenção da mitologia social atuante na Espanha do XVII.

Diríamos que no tocante à totalidade narrativa da peça temos uma "mitologia da obediência" às instituições sociais (valores considerados perenes como a honra, o poder político, a religião) ou uma "mitologia do castigo", sendo a estátua do comendador o herói da história e Don Juan seu opositor. A imagem heróica da estátua como legítimo representante do bem é o que confirma a dimensão mítica do outro, pois sem o convidado de pedra para detê-lo e castigá-lo, Don Juan seria apenas mais um trickster.

${ }^{88}$ CAMPBELL, J. O poder do mito. São Paulo: Palas Athena, 2001. p.32
${ }^{89}$ Idem, ibidem. 


\section{CARÁTER SOBRE-HUMANO}

Don Juan executa proezas que o afastam do comum dos homens, mas possui uma dimensão antropomórfica, que o faz parecer humano. Como veremos, ele está substancialmente oposto ao conceito de humanidade, que tomamos aqui emprestado dos latinos e humanistas do Renascimento, conforme os estudos de Maria Helena da Rocha Pereira ${ }^{90}$. A primeira noção de humanitas engloba a idéia de natureza humana, aquilo que é característico do ser humano, modos de comportamento que the são próprios. Dessa idéia original, deriva uma segunda noção, que é o sentimento de simpatia ao próximo, de filantropia, ou "ação humanitária". Essas duas primeiras acepções se referem basicamente ao indivíduo tomado isoladamente. Já no plano social, tem-se mais duas possíveis significações de humanitas: a primeira é a oposição à selvageria, sendo equivalente à civilidade, à aculturação, se associando à cordialidade e à mansidão - isto é, os homens, antes dispersos e violentos, aprenderam a convivência em grupo, subjugando-se às leis e usando da mansidão, ou seja, limitando sua conduta; a segunda diz respeito à cultura propriamente dita, no sentido de educação espiritual e intelectual - é a formação do indivíduo dentro do grupo, a transmissão social da cultura (tendo resquícios do conceito grego de paidéia). Vejamos o modo como Don Juan se afasta substancialmente dessa "humanidade", em qualquer uma de suas acepções.

Don Juan está muito longe de partilhar do sentimento do "homem universal" pois seu modo de comportamento é ímpar, e sua singularidade o destaca dos demais, dos seus supostos semelhantes. Ninguém está mais distante desse primeiro sentido de "humanidade", principalmente no que tange à noção do tempo, que lhe falta, um atributo humano por excelência, que diferencia o homem dos animais e dos deuses. A noção de tempo traz a consciência de finitude - e finitude / limitação é uma característica ausente em Don Juan.

\footnotetext{
${ }^{90}$ PEREIRA, Maria Helena da Rocha. Op. cit.
} 
O burlador tampouco conhece as noções de apreço ao semelhante, de simpatia ou de ação humanitária, presentes na segunda definição. Para ele, é como se o outro não existisse - ou existe apenas como platéia, que não é exatamente um "outro" e sim uma massa informe, que the reconhece as façanhas, validando-as ${ }^{91}$. 0 único "outro" que Don Juan reconhece como legítimo, como digno de atenção, é a estátua, uma instância sobrenatural: ao que parece, Don Juan só pode reconhecer como seu semelhante um ente sobre-humano. Do contrário, não há a mínima ocupação com os problemas alheios, causados por ele próprio. Não há nenhum traço de remorso ${ }^{92}$, mesmo tendo burlado a amada do amigo, o Marquês de la Mota.

Passemos agora à terceira acepção de humanitas, aquela que se opõe à bárbarie, ao representar a vida em comunidade. Diz respeito ao uso das leis, direitos e deveres, em nome do bom andamento social. Claramente se nos apresenta a impossibilidade de Don Juan inserir-se nessa "humanidade", pois o que ele faz é instaurar o caos social, desobedecendo suas leis e fugindo de sua justiça. É exatamente o oposto da civilidade.

Já na quarta acepção encontramos o ideal de desenvolvimento humano, relacionado à formação do homem dentro da cultura, como receptor do legado espiritual e intelectual desta. E aqui precisamos de algumas adaptações da nossa idéia ao conceito, excluindo uma parte deste. Não faria sentido analisarmos a personagem em termos de educação formal recebida, e sim avaliarmos se, de alguma forma, apreendeu princípios da cultura em que se encontra, ou seja: teria Don Juan algum resquício do legado espiritual / cultural da sociedade espanhola dos séculos XVI, XVII?

\footnotetext{
${ }^{91}$ A respeito dessa relação que Don Juan estabelece com a sociedade como platéia de suas façanhas, há uma excelente observação de Renato Janine Ribeiro, que nota que a personagem opera uma mudança na acepção da palavra "público", que passa do sentido político, de espaço comum a todos, ao teatral, de platéia. Don Juan usa o espaço público como se fosse sua platéia. "Fazendo-se espetáculo, ele garante que não exista mais rival para seus feitos, ou controle para suas ações. O poder religioso foi descartado, dispensando-se o padre da cerimônia religiosa, excluindo-se da consciência a moral cristã; o poder temporal tornou-se irrelevante, já que o governante perdeu a praça pública, reduzida, de ágora, a cenário. Isso é talvez o que há de mais notável na ação de Don Juan: ele domina os homens por um recurso único, exemplar, o de teatralizar o social". RIBEIRO, R. J. A política de Don Juan. In: RIBEIRO, R. J. (Org.). Op. cit., p.16.

${ }^{92}$ De fato, como aponta Mario González, não pode sentir culpa, já que carece da noção de tempo retilíneo, onde caberia a consciência de um passado a ser redimido num futuro. Cf. GONZÁLEZ, 2004, p. 27.
} 
Temos em mente, principalmente, o legado da religiosidade católica, um fator sempre determinante ao pensarmos tal sociedade e ao pensarmos, obviamente, a obra religiosa que é El burlador de Sevilla. E neste ponto as coisas se complicam: a princípio, Don Juan parece realmente ser o diabo encarnado, contrastando seu comportamento com qualquer ideal cristão de conduta. E ele efetivamente é assim. Porém, devido à finalidade didática da peça, Don Juan não pode bater de frente com o discurso religioso. Como já vimos, ele não contesta a moralidade católica, simplesmente seu comportamento é alheio a ela. Isso quer dizer, apenas, que devido à intenção pedagógica do autor, a personagem não pode questionar os princípios éticos dessa cultura, mas nos é evidente que não adquiriu para si nenhum dos seus conceitos - e dessa forma tampouco se insere nessa última significação de humanitas.

Parafraseando os humanistas, poderíamos imputar-Ihe o lema: "Tudo do que é humano me é alheio" - e teríamos a dimensão exata, sobre-humana, de Don Juan Tenorio. A identificação de uma persongem com o sobre-humano é facilmente encontrada no tipo de narrativa que conhecemos como mito. Pensamos aqui em consonância com o a definição de Northrop Frye:

\begin{abstract}
Por mito (...) refiro-me primariamente a um certo tipo de história (...) na qual alguns dos personagens principais são deuses ou outros seres mais poderosos que a humanidade. (...) Os personagens podem fazer o que querem, o que significa o que o narrador quer: não há necessidade de ser plausível ou lógico em motivação. As coisas que acontecem no mito são coisas que acontecem apenas em histórias; elas estão em um mundo literário auto-suficiente. ${ }^{93}$
\end{abstract}

Esse caráter poderoso e arbitrário de Don Juan, portanto, parece confirmar sua leitura como mito. Assim, podemos concluir que, apesar da simplificação / esquematização do caráter, Don Juan e a estátua do comendador Don Gonzalo não se tornaram apenas alegóricos, embora certamente possam ser lidos dessa forma. Ambos ultrapassaram a alegoria à qual deveriam estar destinados para efetivar a transmissão de uma moral. Basicamente, ele remetem ao mito por unirem a realidade natural e sobrenatural, colocando-se acima do cotidiano dos homens. A alegoria é apenas uma ${ }^{93}$ FRYE. N. Fábulas de Identidade. Trad. Sandra Vasconcelos. São Paulo: Nova Alexandria, 2000, p. 38. 
forma de se ler o mito. Se pensamos, por exemplo, no da caso da Grécia antiga, vemos que foram os estóicos os primeiros a interpretar os mitos alegoricamente, vendo-os como representações de pensamentos e comportamentos humanos. A explicação alegórica supõe que o mito é uma estrutura ambivalente, tendo um sentido aparente e outro oculto. No caso grego

\begin{abstract}
concluiu-se que, olhado em profundidade, o mito deixaria transparecer um fundo também doutrinal, embora dissimulado, e não apenas poético. Não se trata de uma tentativa para acabar com o mito, mas de uma crítica empreendida em nome de certo tipo de racionalismo. Os mitos não morreram; ficaram apenas sujeitos a interpretações, podendo sugerir outras figuras - menos poéticas - dotadas de princípios normativos gerais, que forma conhecidas como divindades alegóricas. ${ }^{94}$
\end{abstract}

Ou seja, se por um lado podemos ler alegoricamente o protagonista e o antagonista de El burlador de Sevilla como personificações de princípios éticos, por outro, numa abordagem mitológica, os encontramos como seres superiores, que detêm os princípios do Bem e do Mal, e cuja origem remete à rebelião demoníaca. Assim sendo, é possível e pertinente a leitura de Ramiro de Maeztu, que considera Don Juan como a encarnação do mito do poder. Segundo o crítico espanhol, a personagem age como se tivesse consigo um código de direito com um artigo único: o de fazer tudo o que lhe desse vontade. Além disso, afirma que "el secreto de la facinación que Don Juan ejerce, consiste precisamente en su energía inagotable. Esa infinitud dependerá de que no se enamora, de que no se gasta o de que es intrínsicamente inagotable." ${ }^{95}$

Para Ramiro de Maeztu, o fato de Don Juan direcionar sua energia exclusivamente em direção às mulheres se justificaria por serem elas uma espécie de meio-termo entre o concreto e o abstrato. Segundo o autor, ele não poderia se dirigir

\footnotetext{
${ }^{94}$ MITOLOGIA. São Paulo: Abril Cultural, 1973, p. 738. Ainda com o intuito de ressaltar a diferença entre um deus mítico e uma divindade alegórica, vejamos o exemplo de Ares (Marte) deus da guerra e Enio (Belona), divindade que alegoriza a guerra. Enquanto o primeiro detém o princípio bélico, a visão global do guerrear, a segunda expressa a própria luta que se empreende no campo de batalha, sendo a concreção do conceito que está sob o comando de Ares.

${ }^{95}$ MAEZTU, Ramiro. Op. cit. p. 90.
} 
com afã ao dinheiro ou ao poder pois estes seriam instâncias "demasiado abstratas". Se, em vez disso, se dirigisse à bebida ou comida, estaria buscando algo "demasiado concreto". Podemos, no entanto, cogitar outras possibilidades. É possível que Don Juan, caso direcionasse sua energia inesgotável para a bebida/comida, não a estaria gastando e sim acumulando-a. Se a direcionasse ao dinheiro ou ao poder, estaria bucando meios para alcançar seus objetos de desejo - pois embora seja possível o gosto pelo poder e pelo dinheiro em si mesmos, o prazer que proporcionam é sempre da ordem da utilidade, do que pode ser feito através deles. Já com as mulheres, Don Juan não necessita de meios: ele é seu próprio veículo, o acesso às mulheres se dá pelo seu próprio eu - esse eu que faz tudo o que lhe dá vontade, uma verdadeira representação do mito do poder.

O castigo de Don Juan efetua-se pelas mãos de uma instância divina, superior. E não poderia ser de outra forma, pois, como já vimos, as autoridades temporais não podem alcançá-lo. O jantar com a estátua de pedra é o único momento em que o burlador cumpre sua palavra (porque não quer ser considerado covarde, além do desejo manifesto de que Sevilla conheça mais uma façanha sua), pois considera-se à altura da estátua, que também "não é desse mundo". Segundo sua própria fala:

\footnotetext{
Pero todas son ideas que da a la imaginación

el temor; $y$ temer muertos

es más villano temor.

Si un cuerpo con alma noble, con potencias y razón, y con ira, no se teme, ¿Quién cuerpos muertos temió? Iré mañana a la iglesia donde convidado estoy, porque se admire y espante Sevilla de mi valor. ${ }^{96}$
}

Assim, ao enfrentar a estátua do comendador, depara com uma instância que, assim como ele, também "não é deste mundo", porém é sua afirmação positiva, representante legítima dos ideais da sociedade católica de seu tempo e, portanto,

\footnotetext{
${ }^{96}$ Versos 2531-2542.
} 
suprime a afirmação negativa que é Don Juan — afirmação negativa no sentido de que funciona como oposição aos limites dessa sociedade, ou seja, ao negá-los, acaba demonstrando-os, funcionando como exemplum.

Portanto Don Juan não só se identifica com o trickster mas, na verdade, o ultrapassa. Apenas no embate com o seu opositor divino é que ele pode definir-se como figura transcendente; é nesse momento que ele pode ser muito mais do que um enganador incansável, tornando-se a representação mítica dos valores moralmente condenáveis. Neste ponto, temos em mente o que afirma Mircea Eliade

\begin{abstract}
[aos mitos] compete acima de tudo despertar e manter a consciência de um outro mundo, do além (...) Esse 'outro mundo' representa um plano sobre-humano, 'transcendente', o plano das realidades absolutas. É através da experiência do sagrado, do encontro com uma realidade transumana, que nasce a idéia de que alguma coisa existe realmente, de que existem valores absolutos, capazes de guiar o homem e conferir uma significação à existência humana. ${ }^{97}$
\end{abstract}

o que nos leva a concluir que a estátua e o burlador são duas faces do mesmo mito, uma confirmando a outra.

\footnotetext{
${ }^{97}$ Eliade, M. Aspectos do mito. Lisboa: Edições 70, 1986. p.123
} 


\section{CONCLUSÃO}

Ao longo deste trabalho buscou-se averigüar os principais fatores que fazem de El burlador de Sevilla uma obra propícia a dois níveis de interpretação crítica. Em um primeiro nível, temos a peça que trabalha em função de um ideário históricosocial, que é católico, aristocrático, absolutista, contra-reformista e moralizador, perceptível na abordagem que faz de questões como o uso do livre-arbítrio por parte do homem, do casamento baseado no juramento e na consumação física, e em valores como honra, boa-fé, virtude, glória e fama. Em um segundo nível, temos a peça que, ainda com o intuito de reforçar uma exemplaridade, trabalha conteúdos que remetem a narrativas míticas, manifestados explicitamente nas persongens-mitos de Don Juan Tenorio e Don Gonzalo de Ulloa. Ambos os níveis, apresentados nos capítulos 1 e 2 deste trabalho respectivamente, revelam-se como complementares, sendo indispensáveis a uma abordagem que pretenda ser o mais completa possível da obra em questão. Segundo o crítico Rodríguez López-Vázquez, na análise de El burlador de Sevilla:

El problema está en dilucidar el transfondo mítico en que se sustenta: las estructuras antropológicas que permiten su reconocimiento como mito, pero también las preocupaciones personales que hacen que un autor concreto, en una época concreta, articule las bases del mito. En el primer caso estamos en el terreno de la mitografía comparada; en el segundo, en el de la crítica literaria. Difícilmente se conseguirá dar una idea clara del problema si no se atiene el estudioso a ambos niveles. ${ }^{98}$

O autor também adverte quanto à relação inextricável que se estabelece entre a estrutura mítica e o conteúdo histórico que se apresentam:

Este transfondo bíblico, que sustenta los gestos y las metáforas escénicas de la obra, se complementa con un ámbito mitológico que funciona de manera similar.

${ }^{98}$ RODRÍGUEZ LÓPEZ-VÁZQUEZ, Alfredo. Op. cit., p. 26. 
Del mismo modo que los fragmentos textuales y gestuales de cada escena actúan como prolepsis del final, también las referencias mitológicas elaboran un entramado simbólico muy claro. ${ }^{99}$

A articulação de estruturas míticas têm uma funcionalidade dentro do caráter religioso e didático de El burlador de Sevilla, pois, ao ser configurada com traços que remetem ao enredo mítico, que sempre supõe a existência do transcendente, a peça teatral reforça a idéia religiosa que a sustenta. Assim, lemos na estrutura da obra um uso ideológico do mito pela peça, que vai ao encontro do ideal contra-reformista do teatro do Siglo de Oro. Nesse sentido, a personagem de Don Juan submete-se a um enredo cuja finalidade moral é ilustrada por um mito. É no nível do enredo, então, que vemos o funcionamento de um mito que defende a manutenção de uma ordem social. É a interpenetração do transcendente no mundano, do divino no humano - característica básica das narrativas míticas - , que nos mostra que a "realidade", como considerada na obra, está subordinada a esse "plano superior", e deve organizar-se a partir dele - o que, neste caso, significa a subordinação de toda uma sociedade aos preceitos da Igreja e do Estado espanhóis, com todas as conseqüências de suas naturezas contra-reformista e absolutista.

\footnotetext{
${ }^{99}$ Idem, ibidem, p.48.
} 


\section{REFERÊNCIAS BIBLIOGRÁFICAS}

ALBORG, J. L. Historia de la literatura española - época barroca. Madrid: Gredos, tomo II, 1967.

ARELLANO, Ignacio. Historia del teatro español del siglo XVII. Madrid: Ediciones Cátedra, 1995.

ARISTÓTELES. Arte retórica e arte poética. São Paulo: Difusão Europeia do Livro, 1964. Trad. Antonio Pinto de Carvalho

AVILLÉS, VILLAS \& CREMADES. Historia de España: la crisis del siglo XVII bajo los últimos Áustrias (1598-1700). Madrid: Editorial Gredos, 1988.

BAKHTINE, Mikhail, La cultura popular en la Edad Media y en el Renacimiento. Barcelona: Barral, 1974.

BALLESTER, G. T. Don Juan. Barcelona: Destino, 1989.

BERTHOLD, Margot. História mundial do teatro. São Paulo: Editora Perspectiva, 2000.

BLOCH, R. Howard. Misoginia medieval e a invenção do amor romântico ocidental. Tradução de Claudia Moraes. Rio de Janeiro: Editora 34, 1995.

BRUNEL, Pierre (org.) Dicionário de mitos literários. Rio de Janeiro: José Olympio, 2000.

BYRON, G. Don Juan. Nova York: Modern Library, 1949.

CAMPBELL, Joseph. O poder do mito. São Paulo: Editora Palas Athena, 2001.

CANDIDO, Antonio. Formação da literatura brasileira: 1750-1836. São Paulo: Livraria Martins, $4^{a}$ edição. 
CARILLA, Emilio. Manierismo y barroco en las literaturas hispánicas. Madrid: Gredos, 1983.

CARLSON, Marvin. Teorias do teatro: estudo histórico-crítico, dos gregos à atualidade. São Paulo: Editora Unesp, 1997.

DUBOIS, Claude-Gilbert. El Manierismo. Barcelona: Ediciones Península, 1980.

ELIADE, M. Mito e realidade. São Paulo: Perspectiva, 1972.

FREUD, Sigmund. Obras completas. Buenos Aires: Amorrortu Editores, 1994.

FRYE, Northrop. Anatomia da crítica. São Paulo: Cultrix, 1973.

Fábulas de Identidade. São Paulo: Nova Alexandria, 2000.

GONZÁLEZ, Mario Miguel. "Don Juan: burlador, seducido y seductor" In ABREU VIEIRA DE OLIVEIRA, Ester e MIRTIS CASER, Maria (Orgs.). Universo Hispánico - Lengua, Literatura, Cultura. Vitória: UFES/APEES, 2001.

- Introdução. In MOLINA, Tirso de (atribuída). O burlador de Sevilha e o convidado de pedra. Trad. Alex Cojorian. Brasília: Círculo de Brasília, 2004

HAAR, Michel. Introdução à psicanálise — Freud. Lisboa: Edições 70, 1999.

HANSEN, J. A. Alegoria: construção e interpretação da metáfora. São Paulo: 1986, Atual.

HAUSER, Arnold. Maneirismo. São Paulo: Ed. Perspectiva, 1965.

HOCK, Gustav R. Maneirismo: o mundo como labirinto. São Paulo: Editora Perspectiva, 1986. 
KANTOROWICZ, E. H. Os dois corpos do rei: um estudo sobre teologia política medieval. São Paulo: Companhia das Letras, 1998.

KOTHE, Flávio R. A alegoria. São Paulo: Editora Ática, 1986

LEACH, Edmund. As idéias de Lévi-Strauss. São Paulo: Cultrix, 1970.

LEAL, José Carlos. A natureza do conto popular. Rio de Janeiro: Conquista, 1985.

LÉVI-STRAUSS, Claude. Antropologia estrutural. Rio de Janeiro: Tempo Brasileiro, 1973.

LOPE DE VEGA. Comedias. Madrid: Espasa-Calpe, 1952.

Arte nuevo de hacer comedias - La discreta enamorada. Madrid: EspasaCalpe, 1967.

MAEZTU, Ramiro. Don Quijote, Don Juan y La Celestina. Madrid: Espasa-Calpe, 1981.

MARAÑÓN, G. Don Juan: ensayos sobre el origen de su leyenda. Buenos Aires: Espasa-Calpe, 1946.

MARAVALL, José A., Estado moderno y mentalidad social. Siglos XV al XVII, Madrid: Revista de Occidente, 1972.

MC CLELAND, J. L. Tirso de Molina: studies in dramatic realism. Liverpol: [s.n.], 1948.

MENÉNDEZ PIDAL, Ramón. Historia de la cultura española - el siglo del Quijote (1580-1680). Madrid:Espasa Calpe, 1996.

MOLIÉRE, Jean-Baptiste. Don Juan ou Le festin de Pierre. Paris: L’Arche, 1953.

MOLINA, Tirso. Comedias. Madrid: Espasa-Calpe, 1952. 
. El burlador de Sevilla.Edición de Alfredo Rodríguez López-Vázquez. Madrid: Cátedra, 1990.

MORÓN ARROYO, Ciriaco. La controversia "de auxiliis" (sobre la gracia). In MOLINA, Tirso. El condenado por desconfiado. Madrid: Ediciones Cátedra, 1992.

NAUGHTON, Virginia. Historia del deseo en la época medieval. Buenos Aires: Quadrata, 2005.

OROZCO DÍAS, E. Manierismo y Barroco. Madrid: Cátedra, 1988.

. El teatro y la teatralidad del barroco. Barcelona: Editorial Planeta, 1969.

PEREIRA, Maria Helena da Rocha. Estudos da história da cultura clássica. Lisboa: Fundação Calouste Gulbenkian, 1998.

PINTO CRESPO, Virgilio. Inquisición y control ideológico en la España del siglo XVI. Madrid: Taurus, 1983.

RIBEIRO, Lêda Tâmega. Mito e poesia popular. Rio de Janeiro: Funarte, 1986.

RIBEIRO, Renato Janine (org.) A sedução e suas máscaras. Ensaios sobre Don Juan. São Paulo: Cia. das Letras, 1988.

RICO, F. (Dir.), Historia y crítica de la literatura española. Barcelona: Grijalbo, 1980/1992 (9 vol.).

ROSENFELD, Anatol. O teatro épico. São Paulo: Perspectiva, 2004.

ROUSSET, Jean. Le mythe de Don Juan. Paris: Armand Colin, 1990.

RUIZ RAMÓN, Francisco. Estudios de teatro español clásico y contemporáneo. Madrid: Fundación Juan March/Cátedra, 1978. 
1988.

, \& OLIVA, César (coord.) El mito en el teatro clássico español. Madrid: Taurus,

RUTHVEN, K. K. O mito. São Paulo: Perspectiva, 1997.

SAID ARMESTO, Victor Said. La leyenda de Don Juan. Buenos Aires: Espasa-Calpe, 1946.

SANTOS, Laymert Garcia dos. Don Juan e o nome da sedução. In RIBEIRO, Renato Janine (org.) A sedução e suas máscaras. Ensaios sobre Don Juan. São Paulo: Cia. das Letras, 1988.

SHEARMAN, John. O Maneirismo. São Paulo: Editora Cultrix, 1978.

SIMONSEN, M. O conto popular. São Paulo: Martins Fontes, 1987.

SKINNER, Quentin. As fundações do pensamento político moderno. São Paulo: Companhia das Letras, 2003.

STAROBINSKI, Jean. As máscaras da civilização. São Paulo: Companhia das Letras, 2001.

VALBUENA PRAT, A. Historia de la literatura española. Barcelona: Editorial Juventud, 1951.

VAREY, J. E. Cosmovisión y escenografía: el teatro español en el siglo de oro. Madrid: Castalia, 1990.

VITSE, Marc. Las burlas de Don Juan: viejos mitos y mito nuevo. In RUIZ RAMÓN, F. y OLIVA, C. (coord.). El mito en el teatro clásico español. Madrid: Taurus, 1988.

WATT, Ian P. Mitos do individualismo moderno: Fausto, Dom Quixote, Dom Juan, Robinson Crusoe. Rio de Janeiro: Jorge Zahar Editor, 1997.

WEBER, Max. A ética protestante e o espírito do capitalismo. Trad. Maria Irene Q. F Szmrecsányi e Tamás J. M. K. Szmrecsányi. São Paulo: Pioneira, 1967. 
WILSON, E. M. Siglo de oro: teatro, 1492-1700. Barcelona: Ariel, 1992.

WÖLFFLIN, Heinrich, Conceitos fundamentais da história da arte. São Paulo: Martins Fontes, 1984.

ZORILLA, J. Don Juan Tenorio. Madrid: Alianza Editorial, 1985. 